\title{
Consumer perceptions, understanding and use of product related environmental information
}

A literature review of the Nordic knowledge base 



\section{Consumer perceptions, understanding and use of product related environmental information}

\section{A literature review of the Nordic knowledge base}

Charlotte Leire and Åke Thidell

International Institute for Industrial Environmental Economics

Birna Helgadóttir and Stefán Gislason

Environice, Iceland

Erja Pylvänäinen and Mari Niva

National Consumer Research Centre, Finland

TemaNord 2004:539 


\section{Consumer perceptions, understanding and use of product related environmental information \\ - a literature review of the Nordic knowledge base}

TemaNord 2004:539

(C) Nordic Council of Ministers, Copenhagen 2004

ISBN 92-893-1050-2

ISSN 0908-6692

Print: Ekspressen Tryk \& Kopicenter

Copies: 110

Printed on paper approved by the Nordic Environmental Labelling.

This publication may be purchased from any of the sales agents listed on the last page.

\section{Nordic Council of Ministers}

Store Strandstræde 18

DK-1255 Copenhagen K

Phone (+45) 33960200

Fax (+45) 33960202
Nordic Council

Store Strandstræde 18

DK-1255 Copenhagen K

Phone (+45) 33960400

Fax $\quad(+45) 33111870$

www.norden.org

\section{Consumer Co-operation in the Nordic Countries}

The aim of the co-operation in the Nordic Committee of Senior Officials on Consumer Affairs is to promote consumer safety, protect their financial and legal interests, inform consumers and promote their education, and promote consumer influence in society. Exchange of information, reports, and research will contribute to the Nordic consumer policy and provides a platform for joint Nordic presentation in international contexts.

\section{The Nordic Council of Ministers}

was established in 1971. It submits proposals on co-operation between the governments of the five Nordic countries to the Nordic Council, implements the Council's recommendations and reports on results, while directing the work carried out in the targeted areas. The Prime Ministers of the five Nordic countries assume overall responsibility for the co-operation measures, which are co-ordinated by the ministers for co-operation and the Nordic Co-operation committee. The composition of the Council of Ministers varies, depending on the nature of the issue to be treated.

\section{The Nordic Council}

was formed in 1952 to promote co-operation between the parliaments and governments of Denmark, Iceland, Norway and Sweden. Finland joined in 1955. At the sessions held by the Council, representatives from the Faroe Islands and Greenland form part of the Danish delegation, while Åland is represented on the Finnish delegation. The Council consists of 87 elected members - all of whom are members of parliament. The Nordic Council takes initiatives, acts in a consultative capacity and monitors co-operation measures. The Council operates via its institutions: the Plenary Assembly, the Presidium and standing committees. 


\section{Table of Contents}

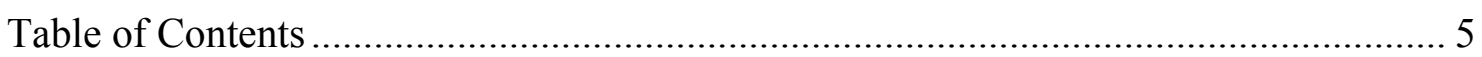

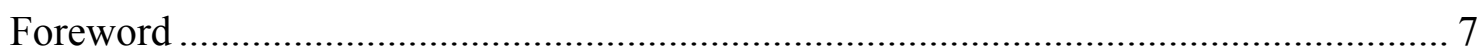

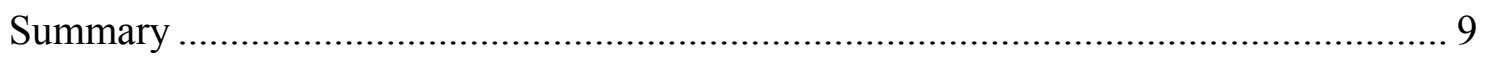

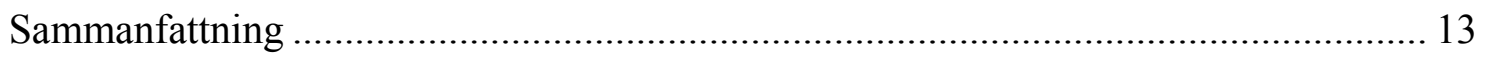

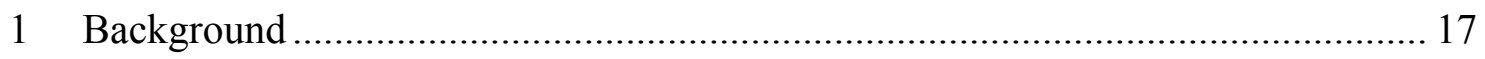

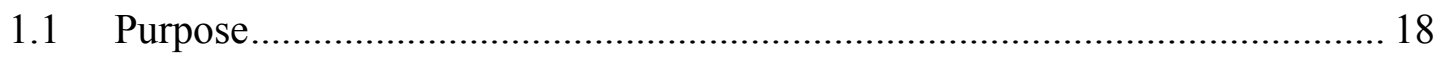

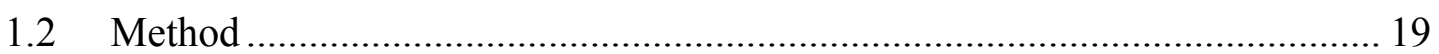

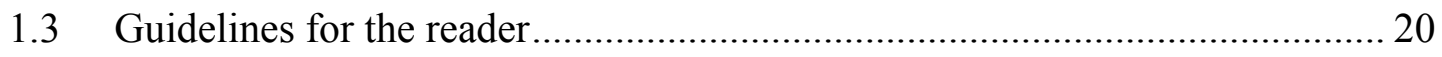

2 Summary of research on Nordic consumers perception, understanding and use of

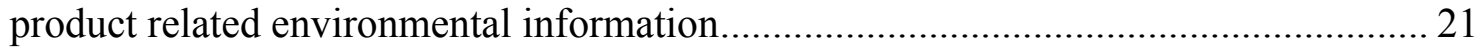

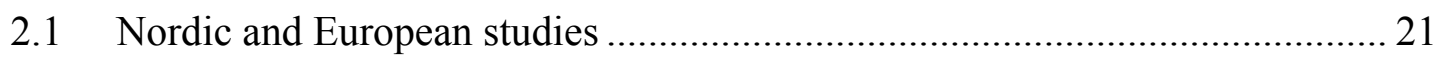

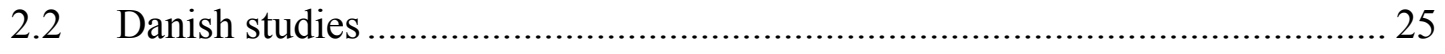

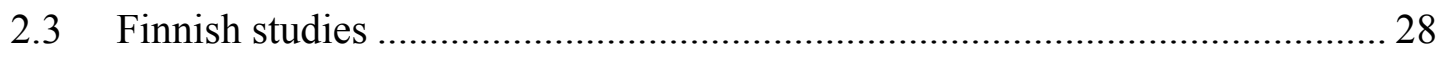

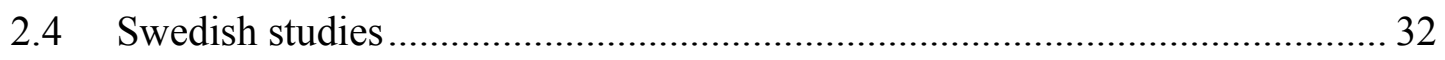

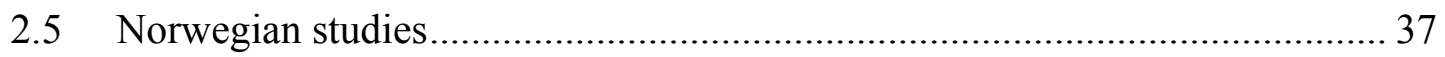

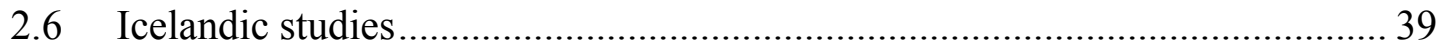

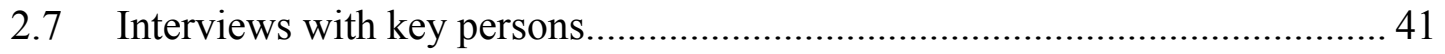

2.8 Environmental segments and purchase criteria........................................... 42

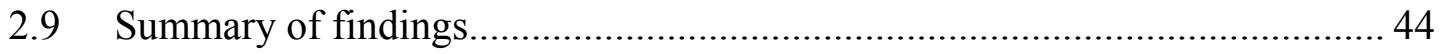

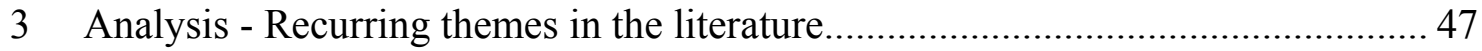

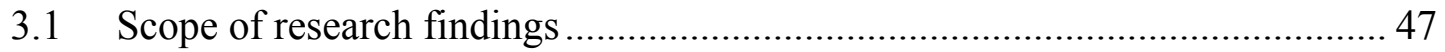

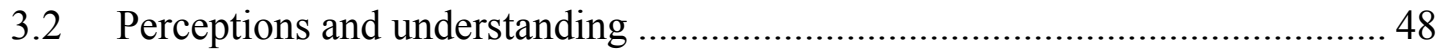

3.3 Use of environmental product information................................................. 52

3.4 Main conclusions from the analysis of the literature .................................... 53

4 Identified knowledge gaps and proposals for further studies ............................. 55

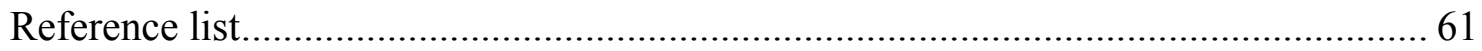

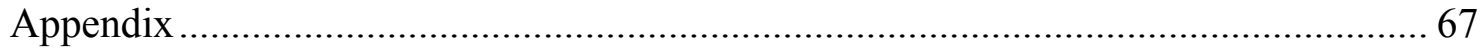




\section{Foreword}

This project has been carried out through cooperation between the International Institute for Industrial Environmental Economics (IIIEE), Lund University, Sweden, Environice, Iceland and National Consumer Research Centre in Finland. Åke Thidell and Charlotte Leire at IIIEE have designed and carried out the research. Åsa Forsberg has provided us with invaluable literature findings. Erja Pylvänäinen and Mari Niva at the National Consumer Research Centre in Finland have been commissioned to compile relevant sources that concern Finland. Birna Helgadóttir and Stefán Gislason at Environice, Iceland have been commissioned to compile relevant sources that concern Iceland.

The project behind this report was initiated by the IIIEE. The IIIEE has in recent years carried out research on issues relating to the different types of information systems for products and services, environmental work in industry and the communication of environmental information along product chains. Many of the studies have pointed to the need for a better understanding of how environmental information is used at the end of the product chain - by end consumers. This knowledge is necessary for deeper studies within the research area of Sustainable Production and Consumption. At the Finnish National Consumer Research Centre, there were several studies during 1990s, using both qualitative and quantitative methods, on the use, interpretations and views of consumers regarding environmental information, especially various environmental labels. In recent years, Environice has been involved in research and consulting regarding environmental information on the Icelandic market.

The Nordic Council of Ministers, the IIIEE Foundation and the Gyllenstiernska Krapperupsstiftelsen have financed the project.

Charlotte Leire and Åke Thidell 


\section{Summary}

This project has been carried out through cooperation between the International Institute for Industrial Environmental Economics (IIIEE), Lund University, Sweden, Environice, Iceland and National Consumer Research Centre in Finland. IIIEE has designed and carried out the research and included findings from colleagues in Finland and Iceland for the literature review concerning their countries.

In recent years the focus of environmental policy making has made the transition from manufacturing processes and point source emissions to product related issues and diffuse emissions to the environment. Product related environmental information systems have been introduced in order to stimulate and foster awareness and knowledge regarding the performance of different environmental products and, for the sake of a more sustainable production and consumption, to stimulate demand for environmentally benign products. Presently, there are many different systems for conveying product related environmental information to consumers and customers. For the information system to be effective, target groups should know how to the meaning and usefulness of the environmental product information.

The purpose of this study is to display current knowledge of how Nordic consumers perceive, understand and use environmental information on products. In this report, Nordic studies, surveys and grounded experience regarding the issue is collected and summarized. The study maps out research coverage and current knowledge. The outcome has been used to identify knowledge gaps.

Most studies reviewed take their starting points in eco-labelling schemes. The literature review reveal a tendency for studies to encompass all product groups covered by different schemes rather than separate them. The Nordic Swan holds a unique position in the research together with national labels for organic food. Relative to eco-labels, a smaller number of studies focus on Environmental Product Declarations (EPD), which cover both self-declarations and quantified declarations. Producers' own self-declared environmental claims are only slightly studied. Studies of the certified ISO Type III EPDs as such are not found. The clear majority of the studies focus on private consumers. Studies on professional buyers in public and private organisations exist but are limited.

The literature review shows a number of themes recurrently researched and reported on. A large number of the studies clearly show that the recognition of the Swan is high to very high in the Nordic countries, followed by organic food labels. In terms of EPDs, findings point to difficulties among both private and organisational consumers to understand and translate the information.

A clear message from most studies conducted in the Nordic countries is that consumer trust in the information is a prerequisite, regardless how the information is conveyed. The trustworthiness of information provided by producer claims was reported to be low. Currently, short and simple information systems controlled by a third party, i.e. ecolabels, seem to be preferred by most consumers. 
Condensed information, such as a symbol, is however sometimes difficult to interpret for the users. Therefore, a number of studies examined propose expanded text information or declarations explaining the environmental features of the products. On the other hand, there are studies reporting that consumers claim to find the amount of available information on products as overwhelming.

Furthermore, consumer confusion on the meaning of all different symbols in the rich flora of label, logos and brands is a recurrent topic and the consumer uncertainty typically relate to organisational and informational issues. It appears that individual consumer knowledge of every single label is generally limited. Instead, the consumer seems to know only a few specific labels. Studies in all Nordic countries report that consumers request additional information to understand the meaning of various systems for environmental product information.

Based on the literature findings, the report was able to identify the following significant knowledge gaps. The following areas are suggested for consideration for further research.

\section{Eco-labelling}

Trust/distrust relate to how schemes are organised, who stands behind them, the environmental relevance of the product group and in what ways labelled products are superior to conventional ones. Because consumers seem to be unwilling to learn more about the meaning of a label on their own, it is relevant to highlight potential ways to complement labels and symbols with explanatory texts or aides. Consequently, ways to increase consumer motivation to buy green products by for example developing evaluation models for the estimation of environmental benefits of a market shift towards eco-labelled products are relevant. The evaluation models should include feedback mechanisms. Additionally, the role of shop display and sales personnel as ecological gatekeepers bears potential for stimulating the demand for environmentally benign products.

\section{Environmental claims}

Current use and trends of claims in terms of how consumers perceive claims in terms of understanding the messages, their environmental relevance and, not least, their credibility are poorly research. It is further important to gain a better understanding of how the control mechanism works in practice and how producers justify their claims.

\section{Environmental product declarations}

The environmental product declarations are in increase and they are sometimes applied as a substitute to other information systems. The declarations need, therefore, to be better understood both from a private and professional consumer perspective. Product declarations are sometimes mentioned to have a possibility to be useful in the market, it is relevant to investigate how to guide and simplify the receiver's use of the information.

\section{Educational attributes of environmental product information}

The information is claimed to serve both as an awareness raiser and a fact provider. There is a general lack of knowledge on which channels appeal and lead to increased environmental awareness and knowledge among consumers. 
There are indications that a portion of consumers are considering product groups that are not open for eco-labelling or lack environmental information to be free from environmental impacts. There is a general lack of knowledge on how consumers view the environmental performance of non-labelled products. Consequently, it would be relevant to investigate how consumers could evaluate and make reflected choices without eco-labels. An aim could be to find complementary information systems for product groups not suitable for labelling.

\section{Dynamics of factors influencing the purchase situation}

Why consumers choose and do not choose environmentally sound/eco-labelled products in different purchase situations is key in understanding the discrepancy between intention and action. It appears to be useful concentrate research closer to the purchasing situation to gain a better understanding. Environmental product information is not alone responsible of greening the market, and as a result, deeper knowledge of contextual factors can facilitate understanding of consumer use of environmental product information in given situations. Further, a more detailed comparison of purchasing criteria in terms of different types of product groups and also type of consumers can identify the potential products that can get increased environmental relevance in the eyes of consumers. 


\section{Sammanfattning}

Projektet som ligger till grund för föreliggande rapport har genomförts som ett samarbete mellan Internationella institutet för industriell miljöekonomi (IIIEE) vid Lunds universitet i Sverige, Environice i Island och Konsumentforskningscentralen i Finland. IIIEE har utformat arbetet och sammanställt resultatet och kollegorna i Island och Finland har bidragit med nationellt relevanta forskningsresultat.

Under senare år har miljöpolitiken skiftat inriktning från tillverkningsprocesser och punktutsläpp till produktrelaterade och diffusa miljöproblem. Information och kommunikation om produkters miljöegenskaper, även kallat produktrelaterad miljöinformation, har introducerats som policyinstrument i syfte att stimulera och främja medvetenhet och kunskap om olika produkters miljöprestanda. Informationen ska bl.a. kunna bidra till att stimulera konsumenters efterfrågan på grönare produkter och därmed bidra till en ekologiskt mer hållbar produktmarknad.

I dagsläget finns ett antal olika system för hantering av produktrelaterad miljöinformation riktat mot enskilda konsumenter och inköpare. För att informationssystemen ska vara effektiva krävs emellertid att målgrupperna förstår ändamålet och nyttan av den produktrelaterade miljöinformationen.

Syftet med den här studien är att redovisa kunskapsläget för hur nordiska konsumenter uppfattar, förstår och använder produktrelaterad miljöinformation. I rapporten är nordiska studier, enkäter och erfarenheter samlade och sammanfattade. Rapporten kartlägger på detta vis forskningens gällande täckning samt gällande kunskapsnivå. Resultatet används för att identifiera kunskapsluckor.

Flertalet av de i litteraturgenomgången funna studierna utgår från olika miljömärkningssystem. Flertalet av dessa studier analyserar samtliga produktgrupper som täcks av studerade märkningsordningar som helheter snarare än att dela upp och analysera skillnader och likheter mellan produktgrupperna. Den Nordiska Svanen, följt av nationella märkningar för ekologisk mat, håller en unik position i forskningen. I förhållande till studier av miljömärkningens effekter är antalet studier av miljövarudeklarationer, både egendeklarationer och miljövarudeklarationer baserade på kvantitativa uppgifter, begränsat. Studier av certifierade miljövarudeklarationer (ISO Typ III) som sådana har inte återfunnits. En klar majoritet av studierna koncentrerar sig på enskilda konsumenter medan studier som berör professionella inköpare $\mathrm{i}$ den offentliga eller privata sektorn är fåtaliga.

Litteraturgenomgången pekar på att en rad olika teman återkommer i undersökningarna. Många studier påvisar en stor kännedom om den Nordiska Svanen och märkning på ekologisk mat bland konsumenter i de nordiska länderna. Studier av egen- och miljövarudeklarationer visar på stora svårigheter bland både inköpare och enskilda konsumenter att förstå och tolka informationen.

Ett tydligt besked från flertalet nordiska studier är att konsumenters förtroende är en grundförutsättning för informationens gångbarhet, oavsett på vilket vis informationen återges. Litteraturgenomgången visar på att konsumenters förtroende skiljer mellan de 
olika informationssystemen. Förtroendet för producenternas egna märkningsordningar och miljöuttalanden var generellt låg medan konsumenterna verka föredra kortfattad och enkel tredjepartsverifierad information såsom t.ex. miljömärken.

Förkortad information i form av exempelvis en symbol är emellertid ibland svårt att tolka för användare. Överlag rapporteras det från samtliga nordiska länder att konsumenter önskar ytterligare information för att förstå betydelsen av de olika systemen för produktrelaterad miljöinformation. Ett antal genomgångna studier föreslår därför supplementär information om produkter, ämnat för konsumenter som inte kan uttolka önskad information från symbolen. Å andra sidan finns det en rad rapporter som hävdar att konsumenter tycker att informationsflödet är tillräckligt, ibland till och med överväldigande.

Vidare rapporteras om konsumenternas förvirring i det rika utbudet av olika märkningar, symboler och varumärken och att osäkerheten till synes grundar sig på otillräcklig kännedom om vilka organisationer som står bakom samt om märkningens avsikter. Det framgår att enskilda konsumenter i allmänhet har begränsad kännedom om flertalet miljömärken men däremot relativt god kännedom om några få.

Följande kunskapsluckor och förslag för vidare forskning har identifierats utifrån litteraturgenomgången:

\section{Miljömärkning}

Hur förtroende skapas och misstro föds beroende på hur märkningssystemen är organiserade, vem som står bakom dem, miljörelevansen för valda produktgrupper och på vilket sätt miljömärkta produkter är bättre än konventionella produkter. Eftersom konsumenter förefaller ovilliga att på egen hand lära sig mer om systemen är möjligheterna att komplettera enklare märken med förklarande text eller hjälpmedel en fråga. Vidare kan nya sätt att öka konsumenters motivation till att köpa miljöanpassade produkter genom att exempelvis utveckla utvärderingsmodeller för uppskattning av miljönyttan av att marknad drivs i en grönare riktning uppfattas relevanta. Vidare bör betydelsen av exponering av miljöanpassade produkter och information om dem vid butikshyllan samt säljarens roll som ekologiska portvakt undersökas eftersom dessa kan fungera som drivkrafter att stimulera efterfrågan på dessa produkter.

\section{Grön marknadsföring och egna miljöuttalanden}

Nuvarande användning och tillämpning av producenters egna miljöuttalanden, hur konsumenter förstår informationen, budskapens miljörelevans och, inte minst, deras trovärdighet behöver belysas ytterligare. Bättre insikt i hur kontrollmekanismerna fungerar i praktiken och hur producenterna motiverar sina påståenden torde också spela en stor roll.

\section{Miljövarudeklarationer}

Miljövarudeklarationerna, i vid mening, ökar i omfattning och har ibland kommit att ersätta andra informationssystem. En ökad förståelse av deklarationernas funktion och användbarhet för enskilda konsumenter såväl som inköpare är därför viktigt. Miljövarudeklarationer förespås få ett ökat genomslag på marknaden, men för detta krävs mer kunskap om hur mottagarens användning av information kan underlättas och förenklas. 
Den produktrelaterade miljöinformationens utbildande egenskaper

Produktrelaterad miljöinformation kan både användas för att tillhandahålla fakta om produkten som sådan men också för att öka konsumenters medvetenhet och kunskap om konsumtionens miljöpåverkan i allmänhet. Förståelsen om vilka kanaler som öppnar för och leder till ökad miljömedvetenhet och miljökunskap bland konsumenter är ännu otillräcklig.

\section{Hur konsumenter uppfattar och väljer produkter ur miljösynpunkt}

Vissa studier indikerar att en del konsumenterna uppfattar att produktgrupper som inte är öppna för miljömärkning eller saknar miljöinformation inte medför någon påtaglig miljöpåverkan. Generellt föreligger en brist på kunskap om hur konsumenter ser på miljörelevans och tar miljöhänsyn vid inköp av icke-märkta produkter. Därmed kan undersökningar om hur konsumenter värderar och gör medvetna val utan hjälp från miljöinformation vara användbara. Ett mål kan vara att finna kompletterande informationssystem för produktgrupper som inte lämpar sig för miljömärkning.

Dynamiken i de faktorer som påverkar köpsituationen

Anledningen till varför konsumenter väljer eller inte väljer miljövänliga eller miljömärkta produkter $i$ olika köpsituationer är förmodligen nyckeln till förståelse för motsägelsen mellan konsumenters intentioner och handlingar. Det verkar som om forskning utförd närmare köpmomentet ger en mer detaljerad bild av hur konsumenter väljer $i$ en given situation och föreslås därför utvecklas. Produktrelaterad miljöinformation är emellertid inte ensamt driva produktmarknaden $i$ en mer miljövänlig riktning. Därför kan djupare förståelse för externa faktorer också bidra till en ökad förståelse. 


\section{Background}

In recent years the focus of environmental policy making has made the transition from manufacturing processes and point source emissions to product related issues and diffuse emissions to the environment. The objective is to decrease the environmental impacts from products and product systems through reduced energy use, using nontoxic and recyclable materials and closed loop material flows. An environmentally sounder product development, market demand for environmental sounder products (goods and services) and improved product use are frequently pinpointed as important measures to reach set goals. The need for increased awareness and knowledge regarding environmental impacts from products and consumption is a precondition for a society on the path towards sustainable development.

A number of product related environmental information systems have been introduced in order to stimulate and foster awareness and knowledge regarding the performance of different environmental products and to stimulate demand for environmentally benign products. One aim is to cause a demand driven shift towards more sustainable production and consumption. Already in 1989, the Nordic Council of Ministers (NCM) introduced the Nordic environmental labelling system. It has been followed by other schemes issued by other organisations. Several labelling schemes are judged successful but have also been criticized. An important issue raised by the criticism is that a simple logo may not provide the customer with adequate information about environmental properties of the products. The development of more detailed environmental declarations is underway and has already been applied and used in certain sectors, for example construction. NCM investigated the potentials of quantitative environmental labels in 1996 (Munck af Rosenschöld, Pripp et al., 1996).

In addition, producers and producer organisations have taken initiatives to develop various models to reach the market with environmental information. A recent study commissioned by the NCM elaborated on the role of the Swan label (Svanen) in relation to other environmental information systems and management systems (Edlund, Leire \& Thidell, 2002). The study highlights many examples of the diversity of information systems that producers use and have experiences from. The study points out the importance of demand by consumers for environmental information and their role in encouraging producers to provide this information.

It is also mentioned that consumers have an uneven understanding and knowledge of product related environmental information. Consumers' need for information vary, even within the different product groups. Producers' own environmental information often contains technical data such as user instructions, environmental and health related information and comparative environmental information useful for a certain product group

Environmental labelling does not compare exchangeable products within the same product group. Within some product groups, labels have also been criticised for having lost effect as the share of labelled products has grown. Environmental labelling can also be deemed inadequate for not providing sufficient information to consumers who want 
to make judgements on their own of the environmental properties of products. Several producers indicate that many customers are sufficiently environmentally literate to begin to demand more product specific environmental information. Certified environmental declarations (ISO Type III) have been considered as a response to this development because they contain large amounts of detailed information. Others, on the other hand, are sceptical to the ability of consumers to process large quantities of product information and claim that the self-declared information together with overwhelming product information in general can cause confusion for consumers. Nevertheless, a large number of self-declared claims exist already today. The Swedish EPA speculates that an increasing amount of environmental information will be more oriented towards producers' self-declarations ${ }^{1}$ and self-declared claims (Type II). (Naturvårdsverket, 2003)

Actors such as producers invest a great deal into producing the information that they want to convey to consumers. It is, therefore, useful to know how much information the customer can process and use at the point of purchase. Among the research projects about different types of information systems for products and services, environmental work in the industry and the communication of environmental information along product chains, the need for a better understanding of how the information is used by end consumers has frequently been emphasized. This knowledge is vital for deeper studies on Sustainable Production and Consumption patterns. A number of studies have been carried out from a producer perspective for different systems of environmental information but research from the consumer and client perspectives seems to be insufficient or under-utilised.

At this point it is therefore reasonable to investigate what type of and how much information consumers can use and understand and if it is possible to find a balance between detailed and simplified, but still useable, information. In other words, the final piece of the puzzle is how consumers relate to environmental information.

\subsection{Purpose}

There are studies on consumer relations to environmental product information conducted in a range of disciplines such as market economics, behavioural science, consumer science as well as psychology. Thus, a challenge is to incorporate existing knowledge in future research. To fulfil the intra-disciplinary demands of environmental management, this study is based on a compilation of findings from the abovementioned academic disciplines. It provides a presentation of relevant research results, experiences and rationales from 1995 to the summer of 2003.

The purpose of this study is to display current knowledge of how Nordic consumers perceive, understand and use environmental information on products.

The further aim of the study is to:

\footnotetext{
1 The self-declaration concept comprises a wide range of declarations where producers report their products' environmental properties, mainly without comparisons or evaluations. These declarations often show similarities to the certified environmental product declarations but are not based on formal lifecycle assessments. They have not been subject to standardization, which also may explain the diverse fashion of displays for the information.
} 
- Collect and summarize existing Nordic studies, surveys and grounded experience regarding consumer perception, understanding and use of productrelated environmental information;

- Describe the current knowledge base and, in so doing, identify knowledge gaps;

- Propose further research corresponding to the identified knowledge gaps.

\subsection{Method}

As a starting point, results from previous studies and experiences on the topic were compiled. At the core of the search for information were the phrases consumer perception, understanding and use of product related environmental information. The following key words were used in the literature search in Danish, Norwegian, Swedish, and English:

- Consumer, customer, purchasing, procurement;

- Environment, sustainable, green, environmentally sound;

- Information, facts, data;

- Environmental declaration, environmental statement, environmental product declaration, brochure, environmental labelling;

- Product, consumption, environmental impacts;

- Knowledge, understanding, interest, use/usage, demand.

The search comprised literature and findings from;

- Surveys and scientific studies of the area;

- Internet searches for articles, debates etc;

- Interviews with key people. In most cases, email preceded a phone call with the contact person interviewed for the third step in the process.

Similar literature searches were conduced in Finland and in Iceland in order to screen the countries for studies and surveys but also to look for people with relevant experience. This study identified 144 related publications (see appendix) that are relevant to the topic. Summarized findings from the 63 information sources (see reference list) that were judged to be of relevance to this report are presented in chapter 2. The gathered material has been controlled in terms of reliable approaches and approaches but no further quality control or exclusion process has been employed.

Telephone interviews and correspondence investigations with 31 professionals (see reference list) were conducted for the purpose of contribution of insightful views and comments. Some interviewees chose to identify useful literature sources.

The aim was to use a threefold method that should capture the relevant literature through a selective process. The process is illustrated in figure 1. 


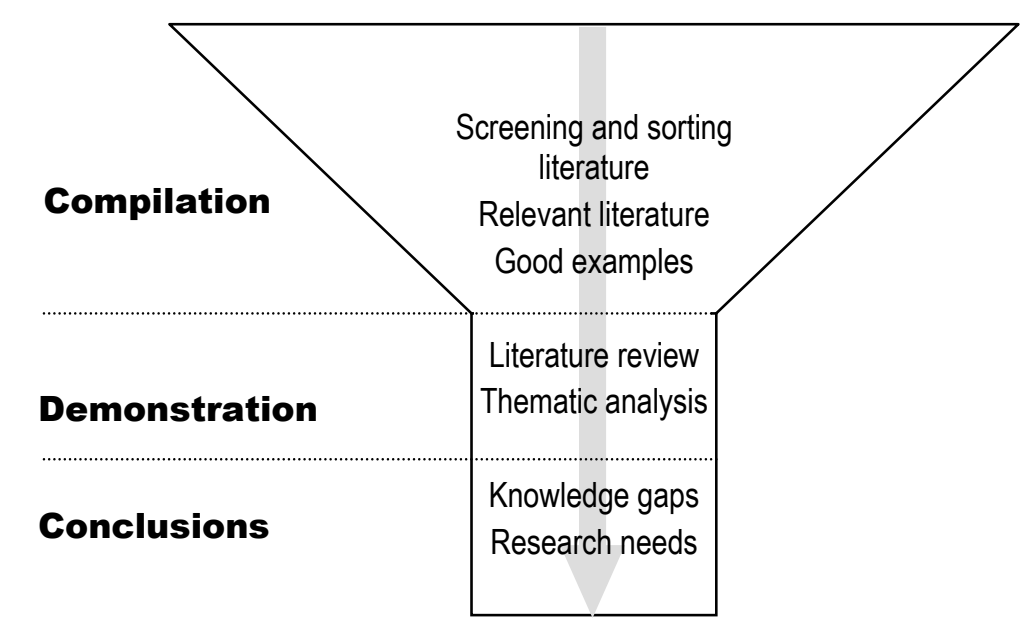

Figure 1. The process of literature search, review and analysis of the knowledge base.

\subsection{Guidelines for the reader}

Besides this introduction, the report consists of 3 main sections:

- Chapter 2 provides a overview of findings and conclusions from the main information sources. The representation is divided into Nordic studies and domestic studies from the Nordic countries. The literature review follows a chronological order, which may illustrate the evolution of the knowledge base. The main messages from the interviews are also accounted for.

- Chapter 3 consists of an analysis of how Nordic consumers perceive, understand and use environmental information on products. The section ends with a general overview of findings and conclusions from the analysis, which further leads to the identification of knowledge gaps.

- Chapter 4 suggests a number of potential research areas, which are based on the identified knowledge gaps.

- Appendix 1 consists of a list of the identified information sources that have been used for the literature review.

A few repeated concepts such as eco-labels and environmental labels, environmental product information and product related environmental information, environmental declarations and environmental product are used interchangeably. 


\section{Summary of research on Nordic consumers perception, understanding and use of product related environmental information}

The objective of this report regard environmental product information and the main task of the research is to conduct a literature review of research from 1995 onwards. The literature findings are categorized within individual sections according to country and in chronological order.

In many cases, studies have been made on broader topics, such as consumer views on Swedish agriculture or how product information in general affects consumer behaviour. These types of studies have in many cases included findings that are relevant to this report, and are therefore also used in the literature review that follows.

\subsection{Nordic and European studies}

\section{TemaNord 1999:592}

A TemaNord report from 1999 explores Nordic consumer lifestyles, knowledge, attitudes and trust in relation to the Swan. The study aims to illustrate how consumers relate to environmental information and eco-labelling and whether the Swan label gives sufficient environmental information to consumers and what the consumers' perceived needs for environmental information are. The study is conducted with 30 focus group interviews involving 158 persons, fairly evenly spread over the Nordic countries. It was supplemented with a survey including, also evenly spread, 3590 interviews via Gallup (a market research company).

The study concludes that the Swan is well known among most consumers, in particular in Finland, Norway, and Sweden where it was spontaneously mentioned by $60 \%$ to $75 \%$ of the respondents. The figures are however lower in Denmark (18\%), and Iceland $(5 \%)$. The lower recognition of the label was explained by the fact that Denmark did not join the Swan scheme until 1997. The study reports, however, results from parallel studies show that a greater share of Danish consumers know the Swan. In addition, the study finds that the Danish Ø-label (Danish state controlled label for organic food) is known by $31 \%$ of domestic consumers and that $16 \%$ of Swedish consumers, unaided, also mention the Krav-label (Swedish organic food label) and 8\% mention the Good Environmental Choice label (Bra Miljöval, an eco-label issued by the Swedish Society for Nature Conservation). In Finland, 5\% of consumers mention the Luomu label (Finnish organic food label) as an eco-label.

Furthermore, the study shows that the Swan has high trustworthiness in Finland, Norway and Sweden and as high one could expect in Denmark and Iceland due to the Swan's limited recognition in these countries. However, the study also finds that Danish 
consumers trust the $\varnothing$-label more than, for instance, the Swan (35\% compared to $10 \%)$. Finnish consumers trust the Swan label much more than other labels $(50 \%$ for the Swan compared to $15 \%$ and less for others) due to the strict control and criteria. Norwegian consumers trust primarily the Swan (70\%). No other label exceeded 5\%. Icelandic consumers seem to rely more on advertisements as a source of information than people in other Nordic countries.

The attitude towards the EU-Flower is however negative among many consumers in the Nordic countries, except in Iceland. Icelandic consumers were also more positive than the others to establish an international eco-label, that could be organized e.g. by the UN. They thought it would be good for the credibility of the label if it would be more international.

The study also reports that a majority of the consumers state that the eco-labels provide insufficient information. For instance, it is unclear who stands behind the Swan label and what the requirements are for labelled products. In combination with the large number of labels, the consumers mix the up and do not know what the difference is between certified eco-labels and plain advertising.

In addition, one finding that few consumers spontaneously identify is the use of ecolabels as guides in purchase situations. This does not necessarily mean that others do not use them. Most consumers mention that the declarations of contents are the major source of information when they want to check the environmental performance of a product. They admit, however, that they do not understand them. (Palm \& Jarlbro, 1999)

\section{NIMBUS}

The Gothenburg Research Institute published a report on the user requirements of certified Environmental Product Declarations (EPD - ISO Type III declarations) that was made within the framework of the Nordic NIMBUS project, which aims for further development of a Nordic EPD system. It was based on focus group interviews in Denmark, Norway, and Sweden complemented by personal interviews with 18 representatives in Swedish companies/organisations. One aim of the study was to describe the conditions for communicating EPD systems both within and between organisations. Moreover, the usefulness of life-cycle data was evaluated. The study is not merely from a consumer perspective, but rather from perspectives of actors in corporate departments such as production, marketing and purchasing in business-tobusiness relations.

The focus group interviews could not identify any significant opinions regarding the EPD system. EPDs are considered superior in relation to traditional eco-labels such as the Swan, which is imagined to be costly, subjective/political, and unfair, as it does not differentiate products in an efficient way. Furthermore, the EPD is seen as more trustworthy as it is built on scientific grounds, is verified and quantitative. Type III information is also considered to be able to increase the environmental competence among those who deal with environmental information. On the other hand, the results show that the comparison between products using environmental aspects on the basis of EPD information is perceived to be difficult and much needs to be done if EPD is to become an effective comparison tool.

The study reports that a number of the interviewees believe that life-cycle based data can be useful for larger customers who need this kind of information for their own 
calculations, that EPD related information is an instrument creating goodwill, that there is generally little demand for EPD information, partly because of the complexity, partly the low levels of environmental specific knowledge among purchasers, that traditional eco-labels are preferred in industries where environmental information is optional and that customers are increasingly demanding information on substance and components. The scepticism toward quantitative data was, in other words, found to be high among interviewees. As for usefulness of the data, some receivers express in the personal interviews that they do not even think that it is possible to rank products on the basis of EPD information as this kind of information is considered too complex and much too time-consuming to work with. A conclusion is that customers should learn about what EPD information stands for.

It is also reported that here is a greater demand for eco-labels and that there is a market potential for this kind of simplistic information. In essence, smaller customers ask for eco-labels and larger actors ask for EPDs. (Solér, 2001)

\section{TemaNord 2001:525}

A literature and pilot study explores how the different Nordic nationalities use labelling on food products. In addition to a literature study, the research includes 15 in-situ protocol interviews with 5 people each in Denmark, Sweden and Norway. The interviews involved a "staged" situation in which the thought processes of consumers were observed through the consumers verbalising their thoughts into a microphone whilst actually shopping. The results then indicated whether or not consumers were reading the labels while shoppingThe general conclusion is that although consumers, away from the purchasing moment, claim to need certain types of information, they do not read many of the labels whilst actually shopping. The report states that consumer habits steer their use of product information, product and purchase place. The in-situ observations identifies that the use of product information is strongly influenced also by when the purchase takes place, and how busy the consumer and the store is. In lowbudget stores, environmental information is given lower priority in decision-making. Another important factor is how consumers trust the retailer. If the trust is high the need to read product information is lower. (Hansen \& Mörch Marckmann, 2001)

\section{TemaNord 2001:573}

Using the literature and pilot study mentioned above, TemaNord continued to explore consumers and food labelling with a Pan-Nordic survey on consumer behaviour and attitudes. On the basis of the results of the pilot study, the survey was designed to be carried out as close to the purchasing situation as possible and to include attitudinal and lifestyle-related factors. The study was performed with in-situ interviews combined with subsequent interviews within which attitude-related explanatory variables where brought into the analysis. 1323 Nordic consumers were interviewed with this method. First, the study finds that Nordic consumers are generally positive towards product information on food products. Variances among the Nordic consumers are found in terms their interest, triggers and use of product information and discrepancies exist with respect to ingredients lists and information on ethical, animal welfare and environmental considerations.

- Danish consumers are characterized as sceptical and, as such, relatively attentive towards labelling information in general. However, they are also critical of production information from food producers and the level of consideration given 
to environmental and animal welfare issues in the production of food. The interest in ecology and the environment is particularly great among Danish consumers.

- Finns are attentive consumers and often read their foods' production information. The trigger for their attentiveness is claimed to be health-consciousness and preference for domestic produce rather than fear of food-related diseases.

- Swedes are found to be the most concerned food customers in the Nordic countries. However, even though Swedes also have many good intentions concerning ethics, animal welfare and the environment, they rarely read product information.

- Norwegians generally give product information a low priority and rarely read information on food products when shopping.

- Icelanders are suggested to be conservative and to mostly select products that they are familiar with. The report suggests that the Icelandic interest in ethical and environmental issues is limited.

In general, consumers do not use labelling information as they feel that they know the products, that they trust the supermarkets, that reading the labels is too much trouble and that time is scarce. In relation to other types of information, environmental information on products is only "somewhat" important among the respondents, and that is for animal products. Environmental information is of no importance for fish, convenience foods or sweets.

Danish consumers are sceptical and more aware of what product information can tell them. They generally have the most positive attitude towards the idea of more product information on labels, including "soft" issues such as ethics, animal welfare and the environment. Also, ethical and ecological issues are generally important to them. Icelandic consumers, on the other hand, are not as ready as consumers in other Nordic countries to pay more for environmentally sound products, and do not read much of the product information, although they are interested to know more about the producers.

Almost all Nordic consumers state that they prefer environmental information in the form of text and not symbols and logos, most likely because they lack sufficient knowledge to understand them. Finns find it especially difficult to interpret symbols and logos and therefore prefer text. A majority of Danish consumers also have problems understanding the logos and symbols and state that they prefer product information as text. Swedish consumers seem to be most familiar with symbols and logos on food and also claim to understand them. However, $56 \%$ of them still prefer product information in text form. The Norwegians prefer text to symbols though they do not voice so many problems in understanding symbols or logos. Only the Icelanders were more positive than consumers in the other countries towards symbols instead of text on the products.

The Danes and Finns among the Nordic consumers are most aware of food labelling and product information, read it, and give it priority when making purchasing decisions. A large number of Finns claim to read the product information, if not in the store then at home. In Sweden, however, consumers claim to read only a limited amount of information and a relatively large group (20\%) never read any form of product information when food shopping. The inconsistency between attitude and behaviour is larger for Swedes than for other Nordic consumers. (Hansen \& Knudsen, 2001) 


\section{TOOLSUST}

The international research project ToolSust explores consumers in the Södermalm district of Stockholm. The most known label was the Nordic Swan. $88 \%$ of the population could mention this label spontaneously. The corresponding figures were $29 \%$ for the Krav-label and 10\% and for the Good Environmental Choice label. Other eco-labels were much less mentioned. 12\% mentioned the Green Keyhole even though it is not an eco-label. Few respondents, less than $5 \%$, claimed they do not know any label or could not remember it at the time of the interview. There was a weak tendency that younger people put more trust in Eco-labels, but in general, the population of Södermalm has a moderate trust in Eco-labelling. It seems that trust is higher than actual behaviour. Among those who had bought white goods recently (39\% of the households) only $19 \%$ had considered energy labelling as a very important criteria for selection of white goods and $22 \%$ did not consider it to be important at all. Women have a slightly higher concern for the environmental and consumption compared to men. (Carlsson-Kanyama, Eriksson \& Henriksson, 2001)

As part of the European ToolSust programme, consumers in Fredrikstad in Norway were studied. The research aimed to give a scientific status to the relation between consumption and environment. One section of the research dealt with shopping activities and food choices. The Swan label was clearly the most known eco-label in Norway. The study found no gender correlation but, on the other hand, age influenced knowledge of the Swan label and a large portion of the interviewees did not take environmental information into account when shopping. (Methi, Stø, Throne-Holst, Vittersø, 2001)

\subsection{Danish studies}

In 1999, the Danish government published a declaration of product labels with an aim to provide background material for the potential development of new labels (such as ethical ones). The study built primarily on a quantitative survey and desktop research and observational studies in grocery stores and qualitative interviews among consumer political actors, private organisations and retailers. The general conclusion about all types of labels was that consumers do not perceive the flora of labels as a jungle. Rather, labels are used according to need. The study argues for a standardisation of the graphical design of labels (the Swan logo was criticised for not being an obvious symbol of environmental issues) and claims there is a general need for the symbol to be accompanied by short and concise text, as well as a way to show whether or not the label is certified. (Erhvervsministeriet, 1999)

In February 2001, The Danish Environmental Protection Agency (Miljøstyrelsen) launched a major campaign aiming for increasing the recognition and knowledge about the two official eco-labels, the Swan and the EU-Flower, and increasing the sales of eco-labelled washing powder and textiles. An evaluation of the effects of an ecolabelling campaign was carried out via face-to-face interviews before the campaign ( 524 interviews), after the campaign (517 interviews) and half a year later (577 interviews). The evaluation reports that the recognition of the Swan increased from $56 \%$ to $68 \%$, and for the EU-Flower from $16 \%$ to $36 \%$ for the EU-Flower after the campaign. The knowledge about their actual meaning also increased, from $26 \%$ to $41 \%$ for the Swan, and from $4 \%$ to $16 \%$ for the EU-Flower. The trust of the labels remained high throughout the campaign. However, the evaluation could not register any increased 
sales of labelled products. Nevertheless, the report states that the actual sales increased significantly. (Miljøstyrelsen, 2001)

A study from the Copenhagen Business School (Handelshøjskolen) aimed to explore possibilities and barriers for the development and production of environmental friendly textiles. The research involved research on both private consumers and professional buyers, and puts a special focus on the EU-Flower. One part of the study investigates Danish end-consumers' demand of environmentally friendly textiles and a survey with 311 respondents was conducted. The respondents were later used for in-depth interviews. The results showed that health is the only working association of environmental considerations. For some potential consumers, the biggest obstacle for purchases was lack of knowledge about the existence of environmental issues. For others, it was not only a lack of knowledge but also an erroneous perception on the environmental consequences of products. The section that concerns professional buyers builds on a literature study and on empirical data from a qualitative interview with 10 buyers from both public and private organisations. The study concludes that barriers include the limited availability of environmentally labelled textiles. Many buyers buy textiles labelled with Oeko-Tex (Öko-Tex) and only few buyers buy textiles with the EU-Flower. The buyer purchasing the largest share of EU-Flower labelled textiles bought approximately $5 \%$ of the textiles with the label. Further, the study reveals the confusion among buyers about environmental labels. The authors suggest that most buyers only go so far as to consider life-cycle oriented environmental criteria on the textiles. This is expressed in time-related limitations. One buyer, for example, had chosen to develop their own environmental requirements because there was no time to wait for the supplier's approval process. (Neergaard, Andersen \& Bech, 2002)

Poulsen and Juhl conducted interviews in three phases via post and telephones in a sample of 1073 Danish consumers regarding their knowledge and use of labelling schemes, before and after an information campaign. The report aims to enable estimations of the benefits of an eco-labelling scheme, from a consumer perspective.. In addition, significant factors triggering the consumer's processing and use of the information should be exposed. In the study, the Swan label and the EU-Flower for detergents were used within the framework of the elaboration likelihood model. The $\varnothing-$ label (organic food) and the recycling label were recognized by all respondents. The least recognized labels were the Good Environmental Choice label and the E-label and the Swan and EU-Flower were recognised at levels somewhere in between. Respondents felt rather sure about the meaning of the Swan and the Ø-label. The study found that different labels represent approximately the same share of users and nonusers with respect to their knowledge of the meaning of the label. The use of environmental labelling schemes is not just a matter of establishment and communication of their meaning (supply); the results reflect a varying perceived need among consumers to use these labels (demand). The study concludes that $25 \%$ of the consumers know the meaning of the Swan and use it accordingly, while $40 \%$ of them also have the knowledge but do not use it for purchase decisions. On the other hand, a group of almost $30 \%$ of the consumers barely know the existence of the label and its meaning, while a small group of $6 \%$ recognise the Swan but are not motivated to achieve further knowledge about it or use it for purchases. According to the study, the difficulty to understand or get an overview of the labelling schemes is generally agreed among the respondents. The moderate usefulness of labels is, on one hand, influenced 
by this confusion and on the other, by an approximate equal trust for all labels. (Poulsen \& Juhl, 2002)

A report from the Institute for Local Government Studies - Denmark (AKF) analyses the effect of the Nordic Swan label on Danish consumer choices among different brands and willingness to pay (WTP) for labelled products. The core of analysed data has been drawn from GfK Danmark's consumer panel and Gallup Adfacts. The study focuses on the toilet paper, paper towels, and compact detergents product groups, for which data were obtained for the four year period from 1997 to January 2001. The data were collected from, on average, 1596 households that reported their weekly purchases. Brands were recorded using bar codes. Altogether, the study is based on 45796 purchases of toilet paper, 28198 purchases of paper towels, and 16738 purchases of detergents, covering a period of 213 weeks. The report concludes that the expected effects of price and special offers are generally obtained from the choice of brand. In addition, it appears that the Swan label had a significant influence on the choice of toilet paper, detergents and, to a lesser extent, on paper towels. There is an actual and significant positive marginal willingness to pay in the range $10 \%$ to $17 \%$ of the price for a certified environmental label on toilet paper and detergents. It seems however that WTP is generally lower for paper towels. It was also reported that the share of environmentally friendlier brands of toilet paper would drop by $6 \%$ to $7 \%$ and detergents by $4 \%$ in absence of a certified label. The report also renders previous studies on consumer knowledge on the Swan. As different methods have been used, the data series not comparable. One series show that the recognition of the Swan has increased from $29 \%$ in 1998 (whereof $33 \%$ could also give a correct explanation to the label) to $56 \%$ in 2000 (whereof $45 \%$ with correct explanation). The correlating figures for the other study indicated that $38 \%$ of the Danes could provide a correct explanation of the Swan in 1998 and 46\% in 2000. (Bjørner, Gårn Hansen, Russel \& Olsen 2002)

The Danish Environmental Protection Agency investigated consumer possibilities and interests in purchasing green electronic goods in 2002. The aim of the study was to examine the relationship between consumers and retailers, their respective and reciprocal perceptions and the possibilities to gain competitive advantage from environmental friendliness in the selling and buying of electronic goods. The study involved one quantitative consumer survey reaching 701 consumers and two qualitative focus group interviews with, in total, 17 consumers that had a somewhat neutral attitude towards environmental issues. Motives and associations to trigger environmental care included extra quality and health aspects and environmental and energy consideration such as economic saving. Furthermore, environmental care gives products an immaterial or symbolic added value, according to the participants in the research. The quantitative survey shows that consumers have a will to prioritise environmental considerations when purchasing electronics but also perceive a lack of available environmental labelling and environmental information when navigating through their purchase decisions. The consumers want simple and clear environmental information that is controlled by the authorities. The trust in uncertified environmental information that is delivered from manufacturers is lesser. All focus group participants want more environmental information and are, in general, more positive towards a simple environmental declaration in comparison to the eco-labels (the Swan and the EUflower) as it conveys information on a few selected environmental parameters. However, if the environmental declaration is uncertified, then they prefer the official 
eco-labels. However consumers prefer labels that are controlled by authorities (Jensen, Sørensen, Schmidt, Grinderslev \& Hjelmar, 2002).

In 1996, Holm and Kildevang investigated purchasing criteria and the discrepancy between consumer intentions and actions in purchasing eco-labelled products. Empirical data were collected from qualitative interviews with 20 families in Copenhagen. The study found that many consumers feel that they lack time and money when they are in the store. Feelings of incompetence and the use of techniques to handle tired children were also expressed. Strategies entailed avoiding looking at the product labels or to look at only some of them. The participant reflected that these strategies were inconsistent, and as such undesired, but that they felt forced by the circumstances to act in such ways. (in Unger, 2002)

A study from the Danish EPA (Miljøstyrelsen) aims to identify the barriers that designers and buyers have in placing environmental demands on suppliers and clarified how retailers in the textile industry view the options of selling environmentally labelled clothes. Interviews were conducted with buyers from 8 different companies. The study finds that there is much confusion on the various eco-labels that are available for producers. Additionally, the final effect on consumers is unclear; retailers participating in the study claimed it is likely that the symbols signalling environmental friendliness are more negative than positive. For instance, the profile of the Swan label is seen as rather old-fashioned and boring. "It is hard to be an underground designer type and to be seen with such labels. The eco-labels are also seen as late-eighties-like, and therefore not very positive to wear. One of the interviewees was interested but wanted the label to look good, as opposed to the EU-Flower, which is not nice-looking and therefore not symbolizing quality. (Himmelstrup Dahl \& Hjort, 2002)

\subsection{Finnish studies}

A Finnish study looked at how consumers obtain environmental information, their level of environmental knowledge and also how they view environmental information. The report suggests that people may know more about issues that relate to their own activities than about environmental problems in general. Although a majority of the respondents considered the dosage of detergents important with respect to environmental impact and they knew about the availability of detergents labelled with environmental information, they still experienced problems when comparing products from an environmental point of view. Consumers further claimed to have difficulties in understanding the environmental properties of products and did not regard the received information as reliable. As a result, according to the study, even though consumers regarded environmental labels as the most important source for environmental information and this information was available in a highly relevant product group, decision-making was difficult. The data was collected in 1614 interviews as part of Statistics Finland's study "Consumption, knowledge, attitudes and environmental policy". (Heiskanen \& Timonen, 1995a)

The environmental awareness of consumers, their knowledge about the Swan label and its influence on their purchase decisions is the topic of another report from 1995. As a result of the study, Vanninen and Viinikainen reported that consumers feel that their knowledge about the label was quite modest and called for efforts to spread the awareness of environmental labels on products. $75 \%$ of the respondents in this study knew of the Swan label and almost all supported additional information on products. 
However, consumers ranked price, availability, quality and appearance before environmental friendliness when making a product selection. The data comprised telephone inquiries with 300 consumers living in the Mikkeli area. (Vanninen \& Viinikainen, 1995)

The decision-making process was the focus in a Finnish study using three categories of consumers depending on their knowledge-level. All in all, 60 persons were interviewed in protocol interviews. The study was part of a Finnish program on consumer habits and energy conservation. Using the protocol method the thought processes of respondents at the time of decision-making were recorded and analysed with the help of coding. Participants were asked to select on the basis of information. The decision-making of the groups with low and average knowledge was "governed by images and simplification". In general, decisions were based on familiarity of brand name and low price. (Kuusela, 1995)

Within the same program on consumer habits and energy conservation, Kuusela later focused on factors affecting the acquisition of domestic appliances and energy savings. One of the aspects considered was how well respondents understand energy labels and how many notice them. Two out of three respondents claim that energy labels help in measuring energy economy and helped people to compare equipment. However, the remainder did not know or understand the purpose of energy labels. Forty-four percent of respondents had noticed energy-labels. (Kuusela, 1996)

Consumer preferences among the characteristics of different types of labels are the topic of a study from 1996. In this study, nearly all knew of the Swan label, more than half had seen the energy label and the green dot, whereas the Good Environmental Choice label and the EU-Flower were less familiar. The Swan and the energy labels were regarded as relatively reliable. The study suggests that even though consumers are interested in environmental information on products, the information is perceived as difficult to understand and moreover, that there is not enough of it. Consumers want information that is" clear, understandable and easy to read", and that "enables them to make environmentally competent choices without having to question the reliability of the information". The authors propose that the Swan or EU-Flower accord with most consumers' needs and desires when it comes to uncomplicated products. Environmental impacts were an important choice criterion for only one fifth of the interviewees. The study was based 31 personal interviews consisting of oral and written sections in which the interviewees examined the product information given on packages, identified labels and answered questions concerning their knowledge and attitudes. The interviews were followed by an informal final discussion. The interviews were recorded on tape and the decision-making test was videotaped. (Niva, Heiskanen and Timonen, 1996)

Heiskanen and Timonen found, according a study from 1996, that the consumers who use environmental criteria in purchase decisions make use of the label,. The study documented consumer awareness of the availability of detergents with the Swan label. 1614 Finnish consumers were interviewed in the context of Statistics Finland's research programme "Environment 1994". The study found that many of the respondents encounter difficulties in using the information, i.e. choosing environmentally sound product alternatives. More information about the criteria of the label is needed together with consumer wish for "standardized labelling with easy-to-absorb information". The energy label for household appliances was provided as an example of good product 
information. The link between environmental literacy and environmentally relevant consumer behaviour turned out to be rather weak. (Heiskanen, \& Timonen, 1996)

Dimensions of Environmentally-Sound Foodstuffs were explored in a qualitative study of consumer perceptions. The research conducted 10 personal interviews and 3 group discussions, resulting in 32 interviews. The study explored the kind of perceptions consumers have on the environmental soundness of foodstuffs. In addition, the study examined the attitudes of consumers toward the prices of environmentally sound foodstuffs. The results indicate that consumers understand "environmentally-sound" foodstuffs by means of six dimensions - packaging, artificial substances, animal welfare, natural feed and fertilizers, non-polluting agricultural enterprises and processing industries - as well as water and wastewater. (Tiilikainen, 1996)

The ways in which consumers search product information and evaluate alternative products is explored in a study about the purchase decision-making process of environmentally conscious consumers. The scope of the study includes various environmental choice criteria such as packaging and recyclables. Despite environmental considerations beyond just environmental product information, the results of the study suggest that insufficient information on environmentally friendlier product alternatives is the biggest obstacle for environmentally conscious consumers. Consumers desire more environmental product information and a declared country of origin. Two focus group interview sessions with 6 persons in each session were run within the study, the participants of which were recruited from two eco-stores in Helsinki. (Armila \& Kähkönen, 1997)

The Swedish School of Economics and Business Administration (Svenska Handelshögskolan) published a report in 1997 on the extent of the influence of environmental labels on the purchase behaviour of Finnish consumers and their use of environmental labels to guide the purchase selection. 28 personal interviews were made at the respondents' homes followed by a peek into the respondents' closets to see what kind of laundry detergent the respondent used. Additionally, a questionnaire was distributed to 107 consumers passing by in a shopping centre. The questions were divided into four parts: values, attitudes, behaviour and willingness to pay. Although the interviewees' attitudes toward environmental labels were positive and there was a stated willingness to pay a higher price for environmentally friendlier products, the majority did not buy any environmentally friendly products (detergents). 50\% of the interviewees believed they bought environmentally friendly detergents, but in reality did not. The study proposes that a contributing factor is the lack of knowledge of the meaning of the different labels. Also, certain brand names and colours resembled environmental statements. Only sometimes or rarely did they actively examine environmental labels, according to the interviewees. The study conclusions shed positive light onto consumers by suggesting that consumers want to use environmental information in their decisionmaking. (Björk, 1997)

Another Finnish study explores environmental labels in the market. Using the Opinio survey over three consecutive years, the study showed that the number of people who recognized the energy label increased from one year to the next. Fewer than half of the consumers who had bought refrigeration equipment in the last 5 years had noticed its energy consumption. This increased to $66 \%$ the next year. For those respondents who made use of environmental information, the primary source of information was salespeople, followed by leaflets and brochures available in the store, and lastly, 
labelling on the equipment. Slightly less than half had made note of the equipment's energy consumption. (Kuluttajavirasto, 1997)

A Finnish study focusing on energy, researched how citizens view electricity energy labelling. A sub-question examined consumer perceptions of the reliability of various sources of environmental information and also views on environmental ranking of electricity. Respondents clearly approved of a grading system in which electricity would be classified into different quality grades by its environmental soundness and by earmarking electricity that meets certain criteria. There was a clear preference for third party verification given to some independent standardization organization to govern an environmental certificate. A Nordic joint labelling scheme won wide approval, indicating that respondents feared too many labels in the market. $40 \%$ preferred a points system and many others opted for product specification forms. (Kiljunen, 1998)

According to the study conducted by TOY Research for Finnish Standards Association SFS/Environmental Labelling, 95\% of Finns say they recognize the Swan label when shown and $78 \%$ also know its purpose correctly. Compared to the previous corresponding inquiry in January 1996, consumer awareness of the label has clearly improved. The respective figures in 1996 were 83\% (knew the label) and 73\% (knew its purpose). (SFS, 1998)

In 1998, the Finnish National Consumer Research Centre researched the perspective of the actors in the production chain. One of the questions concerned the availability of relevant information. Nearly all of the participants that represented different actors along the product chain experienced a lack of environmental product information. Also, the environmental information provided by media proved an insufficient base for making comparisons. The Nordic Swan label was regarded as a reliable indicator of a product's environmental quality. On the other hand, the flow of environmental information between consumers, retailers and manufacturers was found to be insufficient. The majority of respondents expressed experienced difficulties in knowing which of the many different labels are reliable. However, they admit not paying much attention to environmental labels or information for products. More information on the background and criteria of the Swan label is desirable and information regarding environmental impacts of a product's life-cycle would make it easier, according to the respondents. (Timonen, Heiskanen, Kärnä \& Niva, 1998)

An international study on experiences with the energy label of the EU member nations found that in 1997, 53\% of Finnish people were sure to have seen the label. (Winward, Schiellerup \& Boardman, 1998)

A later study from the Finnish National Consumer Research Centre aims to assess how well the data given on labels of durable goods corresponded to what the consumers regarded as necessary product information. Consumers placed emphasis on factors that related to the use of the product. Energy labels were found to contain the most comprehensive and detailed product information. (Kanerva \& Timonen, 1999)

Labelling as a means to affect consumer choices is the focus of another study that uses the Nordic Swan label as a case. Respondents were asked questions in the store: whether they knew the Swan label and whether they had used environmentally labelled detergents (i.e. purchased environmentally labelled goods). Nearly all respondents recognized the Swan label. Consumers stated that environmental features in products had a favourable effect on their purchase decisions. The results showed that consumers "hardly inspect" the shelf or product labels. More than half said they had used an 
environmentally labelled detergent but $18 \%$ regarded environmentally labelled detergents as less efficient. The study suggests that the efficiency requirement of the Swan label is, therefore, not clear to consumers. (Asikainen, 2000)

Laaksonen and Mäntylä found that consumers knew that the environmental information given on product packages could help decision-making. The labels had low importance to a majority of the respondents, however, as they had not utilized them. A few respondents claimed that packaging and labels convey "distinctive characteristics" of an environmentally friendly product, no matter what the product is. (Laaksonen \& Mäntylä, 2000)

In a study conducted in 2001 on consumer energy conservation, private households were inquired as to whether they knew the energy label and if it affected their purchase of a product, as well as their knowledge of the Norppa (Saimaa seal) label in particular. $75 \%$ knew the correct meaning of the term "efficient use of energy" and $72 \%$ recognized the Norppa ecoenergy label when shown. Consumers urged for more energy related information from neutral sources and desired justified, practical information and personal advice. (Puttonen \& Wennerström, 2001)

The Finnish Standards Association investigated the knowledge of the Nordic Swan label in 2001, giving corresponding data for the two previous years. $95 \%$ recognized the label when they saw it, which is as good as in 1998 but an improvement compared to 1999. The correlation to understanding the meaning is inversed, that is, in 1999 more respondents knew the meaning than in the previous and following years.19\% of the respondents regarded the products with the Swan label to be of domestic origin. (SFS, 2001)

\subsection{Swedish studies}

During three consecutive years in the early 1990s, The Swedish Consumer Agency (Konsumentverket) conducted consumer surveys with similar questions with the purpose of describing the environmental awareness of Swedish consumers and the ways in which it adjusts over time. A number of parameters were investigated, whereof some are relevant for this review. The findings are based on telephone interviews with approximately 1000 stochastically chosen people in each year.

According to this study, the level of recognition is high. The Swan was known by $95 \%$ of the interviewees, followed by the Krav-label 61\%, the Good Environmental Choice $48 \%$ label and the EU energy label $8 \%$. Moreover, the environmentally profiled private brands (Skona $85 \%$, Änglamark 77\%, and Sunda $41 \%$ provided by the major Swedish retail chains) are, apparently, publicly recognized. It was also concluded that the public has a relatively good understanding of their meaning in terms of connecting them to reduced environmental load, organic produce, etc. It is also reported that the eco-labels have a relatively high trustworthiness, almost $70 \%$ of the interviewees stated that they put very high or high trust in them. When it comes to purchases, $70 \%$ of the population report that they regularly buy eco-labelled washing powder and $47 \%$ report that they regularly also buy other eco-labelled products. The trend increased over the three years.

In parallel, consumer perceptions of the environmental claims stated by manufacturers and retailers were studied. A number of these claims emphasize that the products are environmentally friendly in one or other way. The study reports that $46 \%$ of the population gives the claims a lot or a relatively lot of weight. Various phrases used for 
expressing that a product is environmentally benign were tested. It was found that fact based claims, i.e. "manufactured from recycled material" and "organic produce", are perceived as fairly trustworthy, while vaguer phrases, such as "environmentally friendly" and "lenient towards the nature", are perceived by a majority as confusing and misleading.

The consumers' reasons for not purchasing environmentally benign products were also investigated. Based on three years of studies, the report concluded that a great and stable share of the consumers that perceive declarations of contents and other information on the packages as insufficient, but also that it is difficult to find such products, and that that they are too expensive. $43 \%$ of the population also thinks that environmentally benign products are of lower quality than others. (Konsumentverket, 1995/96)

Gothenburg Research Institute presented a report in 1997 that aimed to identify representatives for professional users of Type III information on products, to highlight the preconditions of professional users to understand and use Type III, and to develop recommendations regarding the design of the Type III information. In the phenomenographic study, 17 interviews were conducted with customers to companies of different sizes and with varying environmental strategies (in this case both companies that implement environmental thinking out of their free will and those who do it because of market demands). Most respondents, including those who were categorized as having a good understanding of environmental issues, needed some kind of explanation for the given label. The report concluded that there is a need to educate users if they should be able to understand and use Type III information. The study also pointed out a need for simplification of the Type III information. Almost all respondents expressed a need for threshold or guiding values in order to compare values and assess products. (Fallenius, Sjöstedt \& Solér, 1997)

In 1998, the Swedish Consumer Agency presented work with the purpose of investigating, among other issues, to what extent and what kind of environmental information various categories of consumers prefer for different kinds of products, how readable texts of environmental labels are and to what degree consumers are able to assimilate multidimensional information. The method in this study involved eleven focus groups interviews with, in total, 64 participants. The results illustrate the participants' perceptions and understanding of graphic, simplified, quantifiable information, quantitative information and fully-fledged product declarations. Fewer consumers are motivated to invest time in interpreting thorough environmental information on everyday commodities. The study indicates that, for instance, the Swan or the graded EU-Flower may be sufficient for most consumers when it comes to uncomplicated products. The (proposed graded) EU-Flower did constitute much of a stumbling block and the authors suggest this is because once a person has accepted the label there is not much text that one can ponder over. The majority of people found the graphic eco-profile was deemed far too demanding and the visual presentation of the data was not received well. Participants also encountered difficulties in reading the quantitative eco-profile and many asked for some kind of reference value or mean data to make possible comparisons between products. However, complex information inspired confidence regardless of its contents, rather than satisfying consumer needs for information before selecting a product to purchase. In conclusion, there is no single environmental labelling system that is adequate for all groups of products and all categories of consumers in all situations. The principal purpose of multidimensional environmental data on products should be to help consumers include relevant matters in 
the decision making process. The authors suggest that product declarations could be useful complements to traditional eco-labels. Allegedly, the trend is that the more expensive and complicated the product, the greater the acceptance for complicated information. (Palm \& Windahl, 1998b)

Another study from the Swedish Consumer Agency investigated the attitudes and actions of Swedish citizens in environmental issues. Among the study, the questions were "how environmentally conscious are Swedish consumers, what is the demand for eco-labelled products and are Swedish consumers knowledgeable on environmental questions?". The study, conducted by TEMO, was based on 1100 telephone interviews with Swedes in the 15-75 age group. The study finds that there is a good recognition of the Swan, the good Environmental Choice, and the Krav-label. 51\% of the consumers stated that they often or always buy eco-labelled products while $25 \%$ reports the same pattern for their purchase of organic food. More than $50 \%$ of the participants say that manufacturers' environmental claims are rather or very important. Women and highly educated people find it especially important. The participants state that they are prepared to pay more for less environmentally harmful products. For instance, $74 \%$ of the citizens are willing to pay $10 \%$ more for organic vegetables. (Konsumentverket, 1998)

SOU, The Swedish Public Investigations, presented a comprehensive publication in 1999 with the purpose of investigating current problems in labelling and other consumer information for every-day goods. The aim was to contribute to the development of information and labelling. One section of the study examines how consumers perceive labelling and other consumer information, and what problems they face with different types of environmental information. The study surveys consumer knowledge and experience of labelling and uses a qualitative investigation on consumers' perceptions via group discussions. The survey was conducted together with the Cooperative "Konsumentgillet" and considers labelling in general. With regards to environmental labelling, it was found that respondents lack some knowledge about certified environmental labelling and cannot separate certified environmental labelling from environmentally profiled product brands or health labels such as the Swedish label Green Keyhole, the WWF Panda or recycling arrows. In group discussions it is found that environmental labelling is well known to most discussants and most claim to want to buy environmental friendly if the price is reasonable. However, many state that they do not study the available environmental labels on daily goods. One reason is said to be scepticism towards the trustworthiness of environmental labelling and an uncertainty to the meaning of them. The uncertainty is expressed in that discussants experience difficulties in distinguishing certified environmental labelling from other types of labelling. (Statens Offentliga Utredningar, 1999)

The MERA association (Miljö, Ekonomi, Resultat och Allergi) conducted a survey to find out the dosage and use of detergents and the link between eco-labelling and overconsumption of detergents. The measured significance of eco-labelling was small. A large number of consumers did not know whether their washing detergent is ecolabelled or not. The survey was based on 1-hour interviews with 107 households. However, most respondents considered that differentiating the detergents, which are more environmentally sound, is important. (Personal communication with Per Lögdlund, MERA) 
Organic food is the focus of one study commissioned by the Association for the Kravlabel and the Swedish Federation of Farmers (LRF). The study was based on a market survey and focuses on consumer profiles and factors such as knowledge, purchasing routines, arguments and attitudes among consumers. For products and services in general, the Swan label is the most known followed by the Krav-label. More than $25 \%$ could not spontaneously mention any eco-label in regards to labelled products or services in general. 12-16\% could not mention any eco-label for the food group. The Krav-label was in turn the most known label in the food product group and mainly associated with vegetables, milk and potatoes. The Krav-label was understood as indicating that the product in question is organically grown and pesticide free and therefore good for nature. The advantage with organically grown food was considered to be environmental concerns, the disadvantage the price. $70 \%$ of consumers lacked information on what the Krav-label and organic farming stand for. The report recommends more consumer information to influence consumer behaviour to a higher degree, i.e. to trigger a positive market development for organic products. (Holmberg, 1999)

In a licentiate dissertation from the IIIEE, the development and use of environmental product declarations in business-to-business communication was reviewed and analysed. The research built on a literature study and interviews with key actors (producers and customers) in three sectors: building, energy, and automotive. The review identified a smaller group of LCA (life-cycle assessment) based certified EPDs (Type III) and a relatively large amount of self-declarations, which are based on general life-cycle perspectives. The report concludes that the information in the declarations was seldom put to any actual use, neither by manufacturers nor by customers receiving the information. The potential explanations are manifold. A significant obstacle is the complexity of the information and that the ability of the professional purchasers to interpret the information is overestimated. Most company representatives judge the information provided as too complex, which is considered as a major barrier for the sensible use of EPDs, and consider that the detailed information is not suited for communication directly with private consumers. The usefulness of environmental product declarations is further limited by a perceived mismatch between information needs of the customers and information provided by the manufacturers. Whereas public purchasers claim that environmental product declarations have a substantial impact on purchase decisions, many manufacturers perceive that the information has a very limited influence. (Jönsson, 2000)

A Swedish study from the Swedish Federation of Farmers together with the Swedish Ecological Farmers (Ekologiska Lantbrukarna) mapped out the lack of knowledge, true vs. erroneous knowledge and values, attitudes as well as demands and wishes among consumers regarding ecological food production. The study used a postal survey to 396 Swedes. Respondents were rewarded with 75 SEK. The findings indicate a great lack of knowledge and a great insecurity among consumers about ecological problems. The word Krav was on purpose not used in the questionnaire, which could possibly have contributed to the low knowledge. With respect to associations, many respondents think ecologically products are better for their health. (Szatek, 2001)

The Swedish Consumer Agency used group discussions (8 groups, 53 participants) to explore consumer interest and awareness about environmental issues and to assess their action from an environmental perspective. The study also aimed to determine what is needed to stimulate environmentally sounder consumer behaviour. Several myths were 
revealed in the discussions, the relevant one being that "ecological products is a business idea to make money" and "environmental labels exist in the name of sales" and "environmentally labelled products are not better than non-labelled ones". A reason for annoyance among consumers was the environmental related paradoxes, such as ecological products packaged in smaller size containers. The groups also expressed distrust towards environmental label schemes, mainly because of the rumours that the schemes existed to benefit the producers through higher sales numbers. Many regarded the Swan and the Krav-labels as trustworthy, though they were suspicious towards the concept of organic food. Organic products were not perceived as everyday goods but rather as "exclusive". A few participants actually looked for organic products as they were considered more expensive. (Konsumentverket, 2001)

In 2002, students from the Royal Institute of Technology investigated how consumers in the housing market value environmentally friendly alternatives. The part of the study that focuses on potential housing customers uses two types of surveys, one applied in two housing exhibitions and one survey sent out to 200 persons who had registered interest in a building project in Sweden. One question determined whether an own environmental brand, environmental package or other environmental guidance is appreciated among customers. Trustworthiness was found as the prime criterion for making customers choose environmental options. Self declared environmental labels were criticized. Participants claimed that demand can be created using simple information about the existence of friendlier options and their environmental advantages. (Ernhult \& Kollberg, 2002)

A report from the IIIEE on behalf of the Swedish Chemical Inspectorate (Kemikalieinspektionen) aimed to collect experiences from the development and use of systems for voluntary self-declarations based on life-cycle perspectives in the building and textile sectors. 100 actors producing and using declarations were contacted in telephone interviews. The study reports that the buyers find the declarations difficult to use. Declarations of building materials are mostly used when searching for specific hazardous substances in purchase situations. They are infrequently used on the construction site. Most interviewees agreed on the need for adequate product knowledge together with knowledge of the applications, as well as chemical and environmentally related issues, in order to be able to use the declarations. Interviewed persons also pointed out large differences in data among declarations for equivalent products, and that they frequently need to request additional data from the supplier. Those receiving declarations for construction material also perceived a varying quality level of the information content. The findings for buyers of textiles were similar in that the quality level of the provided information varies. Environmental product declarations for textiles are seldom used, which is partly explained by the lack of need for such detailed information. In other words, the declarations are deemed too rich in information. Guides or other helping tools for interpreting the information were called for. The impression that most buyers wished for external verification of the data was also registered in the survey. (Kogg \& Thidell, 2002)

The Swedish label the Swedish Seal (Svenskt Sigill) launched an information campaign followed by a consumer survey in the spring of 2003. The objective of the study was to explore consumer attitudes to Swedish agriculture and Swedish foodstuffs and to grasp the knowledge, values and attitudes of consumers regarding Swedish and foreign foodstuffs. The study was based on a postal survey to 1500 persons between 16 and 70 years of age. The study found that approximately $16 \%$ of the consumers are considered 
friends of the environment and aim for a high standard of food safety. The trust for brand names and eco-labels was also measured. The issue of trust utilized a grading system and concluded that the Krav-label and the label for Swedish-grown (Svenskodlat) gained the same trust in 2002 as in 2000, around 75\%, among consumers. $7 \%$ claim that they do not trust the Krav-label. The Swedish Seal had the lowest confidence among consumers at the time of the study. The study claims that in general, most consumers are satisfied with information on origin of the food product. (Szatek, 2003)

\subsection{Norwegian studies}

Consumer need for health and environmental information formed the focus of a Norwegian study from the National Institute for Consumer Research (Statens Institutt for Forbruksforskning), SIFO, in 1997. The study aimed to investigate consumer knowledge, attitudes and behaviour in regards to products containing harmful substances. The study used detergents, paints and to some extent batteries, as case product groups. Among the findings related to environmental information as such (as opposed to information strictly related to damaging substances) were that the Norwegian label Good Norwegian-label (Godt Norsk ${ }^{2}$ ) was only to a limited extent perceived as an eco-label. The label for recycling caused confusion on whether the label meant that the product was made of recycled material, or that the product could be recycled. The Swan is the most known label, which many people associated with detergents. However, the study found much uncertainty regarding who is behind the Swan label scheme and also some scepticism as to its criteria and what the label guarantees. Consumers were unsure what the label points to, the product or the packaging. Another part of the study involved focus groups to discuss perceptions of labelling. Women were more reluctant than men to take in the information on liquid detergents. The study suggests that because women handle detergents more frequently than men and thereby pay less attention to the labels in the purchasing situation. In another discussion on readability and understandability based on the paints product group, participants explained that they experienced information on the packaging as "heavy" and could therefore not be bothered to read it. The authors interpret "heavy" as technical and difficult. (Tufte \& Lavik, 1997)

SIFO published another study in 1997, also focusing on health and environmental labelling of products. In this study, the focus was on consumers perception of product labelling with environmental self-declarations (Miljøvarefakta). Focus groups were used to discuss reactions to environmental declarations in relation to the product groups of washing detergents, paints and furniture. Fictive environmental declarations with categorized simplified qualitative information served as reference points in the discussions. Participants preferred labels with symbols to those using text. The latter were also criticised for being too anonymous and difficult to read. The need for environmental declarations was not readily grasped and surprised the groups. Sofas were not thought of in regards to health or environmental risks. In the groups with older participants the declarations caused participants to become sceptical towards the actual furniture product. The focus groups also discussed the Swan, as the environmental

2 Godt Norsk is a label for quality and the Norwegian origin. More information available on http://www.godtnorsk.no/. 
declarations, using a simple logo, were sometimes mistaken for an environmental label and as such a competitor to the Swan. The study suggested that consumers need a different type of information for the purchasing situation compared to type of information they need for product use and disposal. The discussions also declare that the Swan in many ways satisfies the information needs of the consumer in the actual purchase moment. Much points to the conclusion that environmental declarations can be of greater use for product use and disposal, according to the authors. Trust is however important for the Swan because the label summarizes much information and declares a product as environmentally "approved". The focus groups also indicated a lack of overview of Swan labelled products. Further the study found that trust is higher for publicly administered environmental information than for producer-supplied information. Finally, the discussions focused on the different types of information sources for environmental product information. Both telephone numbers and the Internet were mentioned in the discussions, but participants found products to be the best means, even compared to product shelves in the store. (Tufte, 1997)

In a SIFO study from 1999 on organically produced food and consumer values and consumption patterns, the recognition and knowledge of the Debio Ø-label was measured. 286 respondents were interviewed. The study finds that the age group most familiar with the label is between $30-44$ years. When asked to identify the labels that signify officially approved organic food production in Norway, only $11 \%$ knew of the $\varnothing$-label as such ${ }^{3} .13 \%$ suggested the Swan. $27 \%$ did not know and $28 \%$ thought that a label called Gartner was such a label. Gartner is merely a brand for which an unusually successful marketing campaign was conducted. With regards to which types of consumers recognize the Ø-label, the study found a correlation to age and household income. (Torjusen, Nyberg, Wandel, 1999)

In 1999 a report was published with the purpose to map views on environmental issues in the hospital sector with special emphasis on acquiring medical equipment. The research was carried out using questionnaires to relevant groups in 19 municipalities. $75 \%$ would personally choose more environmental friendly products of the same quality even if they were more expensive (up to $10 \%$ ). An average of $44 \%$ claimed that they generally ask for positive environmental labelling. (Spilling, 1999)

A study from SIFO found that environmentally conscious consumers are busy with sorting waste and forget to buy environmentally friendly products. The labels Swan, Debio and Good Environmental Choice are not as famous as the labels for waste separation. Further, the Norwegian labelling association claims that 4 out of 5 consumers have seen or heard of the Good Norwegian-label. (Methi, 2000)

As part of the European ToolSust programme, consumers in Fredrikstad in Norway are studied. The research aimed put forward what roles households and consumers play in the environmental measures and goals of the city. One section of the research dealt with shopping activities and food choices. Data was collected through telephone interviews with 558 persons. The sample was weighted according to official population statistics for the area. The Swan label was clearly found to be the most known eco-label in Norway. However, the survey also reported indications that environmental information

\footnotetext{
${ }^{3}$ Though there is no official label for organic food in Norway (Torjusen, Nyberg, Wandel, 1999), Ø-label is a private registered label owned by Debio and is considered on track with national and international rules. More information available on http://www.debio.no/
} 
is not influencing peoples' choice of, in this case, groceries. Another finding was that consumer trust in eco-labels alone cannot explain why people are, or are not influenced by environmental information when shopping groceries. It is also reported that consumers in Fredrikstad do not consider the energy label when purchasing whitegoods. (Methi, Stø, Throne-Holst, Vittersø, 2001)

As a contribution to the European DEEP project a paper from SIFO presents an overview of the situation for different eco-labels in the Norwegian market. A collation of studies on consumer knowledge of the Swan label shows that it increased from $12 \%$ in 1992 to $80 \%$ in 1997 . Despite the high recognition of the Swan, only a fraction guessed that the government was behind the scheme. (Strandbakken, 2001)

The focus of a SIFO study from 2001 was consumer knowledge and trust in eco-labels. The research was conducted within the research program DEEP. A consumer survey was carried out in several European countries (1 000 respondents in Norway) focusing on various systems for environmental information on tissue paper products, washing machines and tourism accommodation. Study findings pertaining to Norwegian consumers state that the Swan is well known in Norway and that a number of other labels are also known. In particular, information issued by consumer and environmental organisations, independent bodies and the government is highly trusted. More than $70 \%$ of the Norwegian consumers state that they look for environmental information on tissue paper and washing machines, while only $14 \%$ gave the same statement for tourism accommodation. Eco-labels are also the preferred tool in this product group and consumers mostly do not look at advertising as an interesting environmental information channel. (Strandbakken \& Stø, 2002)

\subsection{Icelandic studies}

Conclusions from a Gallup survey in Iceland with the aim to investigate the environmental awareness among the employees of Landsvirkjun and the people of Iceland found that the Swan label is the best-known eco-label in Iceland;

$36 \%$ know the Swan label, 30\% have heard about the European flower, 16\% have heard about the Blue Angel and 13\% have heard about Good Environmental Choice. 20\% buy ecologically food products always or often; $26 \%$ do sometimes and $55 \%$ seldom or never. $42 \%$ buy environmentally friendly cleansing products always or often; $26 \%$ do sometimes and $32 \%$ seldom or never (observe that "environmentally friendly" is used in the question and not "eco-labelled"). (Landsvirkjun, 2001)

In a report aiming to determine the awareness of The Nordic Swan Label and the meaning of it, interviews were conducted in all Nordic countries. Icelandic respondents to this survey pay less attention to environmental matters when buying products than respondents in other Nordic countries. $50 \%$ of the women never check if the product is environmentally friendly. $31 \%$ of the men tell the same.

The knowledge of the Swan label is less than in other Nordic countries. $29 \%$ of the Icelandic respondents did not know the meaning of the Swan label when they saw a picture of it. This compares with the average $13 \%$ from the other countries. $46 \%$ of the Icelandic respondents knew the Swan label (they connected the Swan label with the environment). (Nordisk Miljömärkning, 2002)

Due to the limited number of studies found on Icelandic consumers, the research was complemented with interviews with nine professional contact persons with relevant 
knowledge on the topic. The contacted persons commented on environmental product information from the perspective of Icelandic consumers. They were contacted on an individual basis, however, the answers were found to be relatively homogenous and it was therefore possible to summarize the answers to each question.

The quantity of products with eco-labels Type I has grown during the last years, but at a seemingly slow growth rate. The Icelandic market offers most of the common ecolabels like the other Nordic countries. There are many products with uncertified environmental information and this is considered to contribute to the confusion among consumers. The impression among contact persons is that there is no product in Iceland with Type III, EPD.

The Swan label is the eco-label that most people know. However, there is a great deal of misunderstanding about which labels are eco-labels. It is common to think that such labels as for example the green dot (der Grüne Punkt) or WWF-label are eco-labels. Consumer information about the Swan label is considered inadequate in Iceland since the label was launched in 1989.

Many Icelandic consumers do not notice or feel concerned with the ecolabels/environmental information. Eco-labelled products are also commonly thought of to have less quality than others. Quality criteria of the eco-labels do not seem to be well known. Some consumers think eco-labelled products are more expensive than others, especially with regards to ecological food products. Health has been the main reason for interest in labelled products. A few respondents said that most people find eco-labels interesting and that most Icelanders are positive towards new environmental solutions. Other respondents said that negative attitudes or neutral attitudes are quite usual. Some respondents mentioned that the negative attitudes towards environmental issues might be explained by the aggressive ongoing discussion about nature conservation of the Icelandic highlands and the building of a new hydro power plant.

Icelandic consumers do not understand environmental product information well. The label-jungle is a problem as it causes confusion among the consumers. There are far too many types of labels. It is also rather usual to mistrust the labels because consumers do not know how the labels are controlled.

The knowledge and awareness of the life-cycle of products is generally low. Most people have some knowledge about the waste-phase and to some extent about the consumer-phase. General knowledge about of the production-phase seems to be lacking, however.

Many Icelanders lack knowledge on the main environmental issues, such as natural cycles and anthropogenic impacts. It is common to connect environmental issues with nature conservation of the highlands or with waste, forestry and other things that easily can be seen. Most people seem to have heard about global environmental problems, but they do not always connect them to their own lives and because of that Iceland has been relatively free of noticeable environmental damage.

Icelandic consumers do not commonly read environmental product information. People buy products that are familiar to them and do not seem to be geared by labels, though it was suggested that consumers read general product information to an increasing degree. It is suggested that it would be better with a short text on the products about what the eco-label means. Moreover, the role of the retailers was mentioned important. 


\subsection{Interviews with key persons}

Key persons who have been involved with the issue of consumers and environmental communication were contacted to bring light to the literature review. The aim was to allow them to voice their personal reflections and thoughts on issues of their choice on the current knowledge of how consumers perceive, understand and use environmental product information and important knowledge gaps.

From a consumer perspective, it was generally agreed that consumers do have opinions on environmental issues and would like to take environmental considerations. It was suggested, however, that consumers, want to be told how to act, not why. Moreover, consumers generally demand that environmental considerations should not cause extra expenses or be complicated.

For many consumers, the concern for environmental aspects of food is a new thing. Consumers are used to considering price, taste, appearance, and other qualities but the environmental aspect is not yet well established in the minds of consumers. It is therefore suggested valuable to explore how to convince the consumers of the environmental relevance of their individual product choices. It was further mentioned that consumers need feedback on their environmental engagement in order to receive positive reinforcement for further environmental concerns and actions.

An important factor in relevant research is the type of approach or method to use. In the comparison with traditional approaches, i.e. consumer segmenting and other classifications, it is time for more complex studies, including long-term research that allows detailed contexts to make use of the knowledge that we do have. It is important to link eco-labels to their context, as there are other aspects that influence actions, and to see how information works in relation to everyday life, how individuals use information and why. The knowledge about factors and emotions behind consumer decision-making that influences their actual choice is considered important. As a result, traditional approaches, on one hand, carry a smaller potential in this field. On the other hand, the value of the in-depth knowledge that results from single discipline approaches is, however, claimed to still be important.

It was claimed that classifications and consumer profiling in segments have sufficiently covered in research. These were regarded as the low-hanging fruit that have already been picked. Additionally, there exists a relatively good knowledge of what information consumers want and their willingness to pay. The problematic area is, however, argued to be the interests that guide consumers and how consumers act according to what information they process. Furthermore, it is crucial to find out which parts of the information consumers absorb and can understand. In order to use environmental product information, the consumers have to go through an evaluation process. It is moreover argued that a reason for consumers to hesitate to attempt an evaluation could be a lack of knowledge on society's general priorities among environmental impacts.

It was furthermore suggested that the information processing required from consumers is intensifying. In this sense, too detailed information can be considered as "false" information when it becomes ungraspable because of the difficulty to process, and as such, loses its meaning.

In terms of what actors are important in the study of consumers and environmental product information, more knowledge was desired regarding the role of the retail store and the sales staff and their influence on consumer behaviour. It was suggested that 
consumers, to a lesser degree search for eco-labels and to a greater extent seek direct information from store personnel. It was mentioned that individuals are part of a social structure and that such studies of individuals lose importance in the context of the social norms and networks that gear individual actions. Rather, this points to a need for knowledge on how norms are spread in groups and networks.

Finally, the discussion that identified the role of brands for consumer uptake of ecolabels is relevant especially because the conventional brands weigh much more than eco-labels currently do. The potential in examining how environmental aspects are integrated into quality issues in the eyes of the consumers was also pointed out.

\subsection{Environmental segments and purchase criteria}

Because consumers are a heterogeneous group, one common approach is to describe consumers in different segments. Segmentation (or typology) is a form of cluster analysis for the purpose of more in-depth understanding of particular groups of consumers. Segmentation builds on the identification of important variables that influence likelihood of consumers to, for instance, engage themselves in certain activities, such as buying green products. Typical variables include age, education, income, gender, neighbourhood, environmental literacy, etc. Describing ecological consumers using only demographic variables can however be difficult (Alarik, 2002). Consumers are to different extents explorative, environmentally concerned, rational and interested in food. It is therefore useful to adopt consumer segmentations with variables that are more advanced than the traditional ones (Hansen \& Mörch Marckmann 2001).

A number of consumer segmentation models have been developed for consumers in terms of their environmental loyalty and preference, and their use of product related environmental information, such as labels (see for example Szatek, 2002, Konsumentverket, 1995/96, Hansen, Knudsen \& Holm, 2001). In 1996, the Swedish Consumer Agency used a segmentation model regarding environmental awareness of consumers. The segmentation is based on both demographic variables and also variables that are more relevant for environmental behaviour. This study has used variables such as habits, willingness to pay, and obstacles for green behaviour (Konsumentverket, 1999/96). The following types of consumers are used:

- The environmental fighters are highly engaged in protecting the environment and therefore are more environmentally concerned at home and when shopping. They are likely to avoid products from certain companies.

- The payers are willing to pay more for products that are environmentally sound. They are domestically active in terms of recycling newspapers saving energy but less active in the store regarding looking for eco-labelled products. Moreover, they do not take position towards certain producers.

- The beginners are ambitious concerning practical chores for the sake of the environment but are below average when looking for environmentally sound products. Their opinions on environmental issues are not always set.

- The sceptics are well equipped with excuses for not being able to take environment considerations, have favourite brands, doubt the quality of environmentally sounder products and have relatively stern attitudes.

- The environmental "sleepers" ignore environmental issues to a large extent. 
A Danish report attempts to segment consumer uptake of specifically eco-labels, with the aim to highlight the added value added of green products to consumers, based on the assumption environmental product information can be processed in different ways by consumers. The report is concerned with many types of labels, both self-declared and certified. Relevant labels include the Swan, the Ø-label and the EU-Flower). The consumer types are described as follows (Juhl \& Poulsen, 2002):

- The label-blind have very little knowledge about the existence of labels and their meanings.

- The exposed can recognise labels but are not motivated to get involved with the labels implications or to use them in the purchasing process.

- The informed neglecters avoid letting labels be a part of the purchasing process.

- The informed users choose to use the label as a purchasing criterion.

The last two consumer types have the capability for information processing in the sense that they know the meaning of the labels, although they act in two different ways.

Typically, the most environmentally active group constitutes between $5 \%$ and $35 \%$ of all consumers. (see Jensen, Grinderslev, Hjelmar, Schmidt \& Sörensen, 2001, Konsumentverket, 1995/96). The group of consumers who use product labelling on food is approximately of the same size (see Hansen, Knudsen \& Holm, 2001).

\section{Purchasing criteria}

When consumers make product selections they usually apply various purchasing criteria. Purchasing criteria refer to the product properties that have an impact on the purchasing decision. Product criteria generally include performance, reliability, conformity with promises, durability, service level, aesthetics and perceived quality (Dobers \& Wolff in Palm \& Windahl, 1998a). In the reviewed literature it was clear that the price is generally the most influential purchasing criteria regardless of product group.

Similarly to consumer segmentation, the analysis of purchasing criteria can be useful for clarifying how high an environmental criterion ranks, i.e. how likely the consumer is to choose a more environmentally sound product.

The importance of the environmental criterion compared to price and quality at the time of the purchase is in fact hard to pinpoint. Consumers rank purchasing criteria differently in different product groups (Palm \& Windahl, 1998a). In addition to product groups, the ranking also varies between Nordic nationalities. Danish consumers are twice as likely, in relation to other Nordic consumers, to consider environmental criteria when shopping (Palm \& Jarlbro, 1999.). The suggested reason is that Denmark is more urbanised and that Danish media put much focus on environmental issues. It is reported in the literature that environmental criterion receive, at best, third place in terms of purchasing criteria (Vanninen and Viinikainen, 1995). Other studies frequently report that consumers rank environmental criteria even lower on the scale of purchasing criteria.

Consumer types, such as those used in segmentations, mainly point to consumer attitudes and intentions. Likewise, the product properties that consumers pay attention to in the purchasing situation can help understand how consumer value products. These descriptions help explain the preconditions for the consumers to use environmental 
product information in their purchases. However, it is a long way from attitudes to action.

\section{Conditions for influencing green product purchasing}

Positive attitude is not a sufficient precondition for consumers to choose green products. For the food product group it has been reported that the influence of a positive views on green products does in general not automatically lead to a purchase of such. Moreover, buying one type of ecological food product does not translate to purchase of another.

Many factors are found that can hinder the transition from attitude to action. For food, habit, convenience and time represent at least a partial explanation of why so few consumers buy organic foods regularly in spite of their positive attitudes. Price is also claimed to be a major, but not the only, obstacle to purchasing organic foods. Other plausible factors mentioned are that most important purchase criteria (taste, health, and quality aspects) do not match consumers' most common beliefs regarding organic foods (more expensive but healthier) (Arvola, Biel, Grankvist, Koivisto-Hursti, Larsson, Magnusson \& Sjöden, 2000).

Similarily, one cannot count on labels to produce high involvement in itself. The isolated consequence, environmental as well as personal, of each individual decision is claimed to be too small in most cases (Thøgersen, 2000). Consumers run the risk of failing to notice an environmental label if the product carries many other labels. If other information that is relevant for the consumer competes for the consumer's attention, even possibly causing information overload, then consumers run the risk of failing to notice environmental labels in the buying situation. Additionally, the purchase can only be influenced by the label if the consumer desires environmentally friendly products (Thøgersen, 2000).

\subsection{Summary of findings}

As reported, various eco-labels including energy labelling, environmental product declarations, and producer's self-declared claims have been subject for the Nordic studies found on how consumers perceive, understand and use product related environmental information. Declarations of contents and messages in marketing have been marginally mentioned without any materialised findings or conclusions. Furthermore, other potential information modes, such as the TCO-label, product tests, articles in newspapers and magazines, technical specifications, etc are notably absent in the found literature.

Among the many alternative means for communicating environmental product information are the eco-labels the most predominant. The Nordic Swan holds a unique position together with national labels for organic food. There are a number of studies on these subjects over the period covered in this report. The indications are quite unambiguous, especially since the trends are steady over the years. In particular is the Swan reported to be well recognised as well as known to a fair degree. In general, the Swan is also reported trustworthy among Nordic consumers. Generally, main national food labels, and in Sweden also the Good Environmental Choice, follow a similar pattern. However, there are studies underlining a confusion that is surrounding the various labels. These studies report that consumers do not fully understand the messages of the labels and co not know the organisations behind, which is the cause for the confusion. In extension, this is a reason for low credibility in all labels. However, 
consumers are apparently positive towards the idea of eco-labels and green products. They state in interviews and questionnaires that they use them in purchase situations and are even willing to pay a price premium for such products. Nevertheless, it is also reported that the actual actions do not correlate to these intentions.

In contrast, producers' own self-declared environmental claims are only slightly studied. The few indications point at low trust in information issued by the producer as such, and also information that is not certified by third parties.

The studies on EPDs cover both self-declarations and quantified declarations. The findings are rather distinct in reporting (both private and organisational) consumers' difficulties to understand and translate the information. Recurrently, it is proposed that the consumers need education to be able to use them. The perceptions of these declarations seem to go in two directions. The predominant is confusion and distrust in uncertified information from a number of different forms of declarations (the certified ISO Type III EPDs are not studied as such). Declarations are, despite that, occurring and demanded in some sectors, for instance building materials. The other direction also indicates insufficient consumer understanding of the information. However, the perception is positive as a declaration offers an opportunity for the consumer to prioritise among the environmental aspects. Furthermore, the fact that EPDs give an impression of being comprehensive, and in particular quantitative, consumers are reported to make a positive and reliable judgement of the environmental soundness of the product.

In general, the examined studies take a starting point in particular environmental product information systems and investigate consumer knowledge and relations to those. Some studies use certain product groups in order to give the research concrete forms. These product groups have, in one or other form, been subject to declarations, claims or labels. There are no studies found that start from any products, with or without set environmental product information schemes, and investigate consumer perceptions and environmental review of those products.

A number of studies investigated the reasons consumers claim for not using environmental product information in purchase situations. The reasons are manifold but the most influential factors are said to be that consumers prioritise price and quality. The preferences for the environmental properties would then be lower. However, habits are also reported to be an important reason for not choosing products alternative to the commonly purchased ones. Interviewees are, furthermore, reported to lack time and resources to search for and examine environmental information in stressed purchase situations. The opportunities to learn more about these factors, however, are likely to be more clear when consumers are studied closer to the purchasing situation. Only a few studies have engaged in these types of consumer observations and interviews. 


\section{Analysis - Recurring themes in the literature}

\subsection{Scope of research findings}

\section{Types of product related environmental information}

A number of studies of eco-labels describe how consumers recognise, perceive and trust them. Issues like willingness of consumers to use them and actual usage is also covered. Some studies report perceptions, usefulness, and trust of declarations including more extensive information of qualitative and quantitative nature. The few studies on selfdeclared claims report mainly on trustworthiness and recognition. A number of these studies bring up the issue of an apparent discrepancy between stated intentions and actual purchase behaviours. These studies are in particular combined with research on eco-labels.

\section{Product groups}

Some studies on the Nordic Swan highlight specific product groups, for instance textiles, paper products and detergents. However, the tendency is to discuss all product groups covered by the schemes rather than separate them and analyse how the label has influenced the individual product groups. Organic foodstuffs is also well represented among the investigated product groups, as it is the basis for most food labels while the studies on energy labelling often begin with domestic appliances or electronics. All studies on product groups are related to specific information provision systems. In contrast to studies that emphasise certain types of information carriers, no studies were found that took certain product groups as starting points, regardless of their affiliation to specific information systems.

\section{Types of consumers}

The clear majority of the studies focus on private consumers. Studies on professional buyers in public and private organisations exist but only limited research covers how these consumer groups specifically perceive, understand and use the product specific environmental information. It is possible that the design of the research question for this report influenced the outcome in terms of the professional buyers; it is however also possible that not that much research covers the issue.

The literature review showed a number of themes recurrently researched and reported. Out of all possible product related environmental information, eco-labels for products and food, environmental declarations, and to some extent, self-declared claims are the primary subjects for the studies. Other means of information, such as declarations of contents, marketing, test reports, etc. are not at all or very little covered.

In the following sections, relevant findings from national and Nordic studies are extracted, merged and summarised under the themes that have emerged in the following section, which is organised for the purpose to answer the research question. 


\subsection{Perceptions and understanding}

Literature findings on consumer perceptions regard green products, environmental product information or a combination of both. The attention of this study is the perception of environmental product information, not to the products as such. The perceptions of the concept of a "green product" influence, however, their view on the information and vice versa. Relevant terminology linked to perception found in the literature is:

- Knowledge of;

- Noticing;

- Association;

- Connotation;

- Trust;

- Confidence;

- Recognition;

- Interest;

- Attitude to labels, statements and declarations.

In this report, the meanings of understanding include both knowledge of, for instance that eco-labels exist, what they mean and stand for, and also knowledge about the ecolabelling schemes (criteria and verification, etc.). In addition, there is a difference between interpreting and understanding, while interpreting is to see more detailed aspects of the information whereas for understanding it is sufficient to simply know the meaning of the label. Relevant terminology used in research that relates to understanding includes:

- Meaning of labels, statements and declarations;

- Meaning of information;

- Meaning of quantitative data.

Labels, logos and brands

Many of the studies described in the literature review, both pan-Nordic and restricted to individual Nordic countries, take their starting points in labelling schemes. Typically they examine and report features like consumer recognition of specific labels, knowledge of their meaning, and perceived trustworthiness. Studies that describe consumer willingness to pay price premiums for labelled or green products and the regularity of purchases are also found.

The Swan takes a prominent place among the reports. Other traditional Type I environmental labels, such as the EU-Flower and the Good Environmental Choice label, are included but to a lesser extent. A second noticeable area of studies examines various national labelling schemes that promote certain quality aspects of food. Labels for organic produce are most frequent but ethical considerations, integrated production, and regional or national production, are also studied. A number of studies also combine research on food labels and environmental labels. Some studies include a number of smaller and sometimes niche labels together with the eco-brands some retail chains 
offer in their assortments. To some degree, and often in combination with studies on energy efficient behaviour, labels for energy efficient products are examined.

\section{Single statements and self-declared claims}

In contrast to the range of studies on eco-labelling schemes, alternative means of providing the environmental claims of producers occur but are apparently not studied to the same extent. The self-declared claims (ISO Type II) are aimed to communicate the views of producers on important environmental features of their products to the consumers. There are no set schemes or any certification mechanisms for this kind of information except the recycling symbol, which may explain the lack of specific studies. The means of communicating product related environmental information consists mainly of information provided in short texts, symbols, or graphic representations.

Studies that included the recycling symbol could report that it is widely recognised by the consumers. However, just a few studies were found on consumer reactions to short environmental statements and claims made by producers. The combined results indicate that the condensed information is difficult to interpret for the users. In addition, the trustworthiness of information provided by producer claims was generally considered low. The conclusion was that the consumers preferred controlled or certified information in order to guarantee the reliability.

\section{Environmental Product Declarations; certified EPDs and self-declarations}

Some Nordic and Swedish studies investigate the perceptions of more extensive descriptive and quantitative information provided mainly through self-declarations and LCA based certified environmental product declarations made by producers (ISO Type III). A Danish study reported findings related to a simplified proposed declaration for electronic goods. Declarations that provide more and detailed information are often said to be used for business-to-business relations but could and are also used for consumer information. In contrast to eco-labels, declarations do not contain any evaluation or judgement of the environmental performance of the products.

Both consumers and professional purchasers that were confronted with such declarations found them difficult to interpret and use. They sometimes raised more questions than they answered as respondents started to ask follow-up questions on the meaning of information. Recurring calls for simplifications and/or guidance such as benchmarks and reference values were however reported in order to be able to use them properly. In addition, the self-declarations appear to have a weak trustworthiness as the information is not controlled or certified. A recurring conclusion from these studies is that the users need to be educated in using them. Despite the difficulties in interpreting declarations, an interesting finding was that some consumers expressed that the extensive and quantified information gave a reliable impression even if they could not evaluate it.

Some of the respondents assume that extensive information might be useful for large professional customers who have capacity to evaluate them before purchase. On the other hand, professional buyers who do not need information for that purpose prefer simplified information and labels. However, a potential use also among consumers was considered. In contrast to grocery shopping, which can be seen as everyday actions often guided by routines and already set purchasing criteria, capital goods investments of durable products are larger and occur more seldom, and therefore allows more careful 
decision-making processes. In these processes, it may therefore be possible also for private consumers to include and evaluate the complex and substantial environmental information declarations.

\section{The inconsistent pictures of recognition, knowledge and trust}

A large number of the studies clearly show that the recognition of the Swan is high to very high in the Nordic countries. The figures reported differ between studies and over time but the general picture is that approximately half of the Icelandic consumers to almost everybody in Sweden recognise the Swan. With a similar pattern, but to a somewhat lower degree, consumers also know the meaning of the system. Frequently, organic food labels are also reported to be highly recognised and known, though still at a lower level. Other eco-labels, for instance the Good Environmental Choice and Demeter (biodynamic label), may be well recognised in individual countries or recognised to a lower degree at the Nordic level. It appears that individual consumer knowledge of every single label is generally limited. Instead, the consumer knows only a few specific labels and regards others, among them the EU-Flower and the energy labels, with less attention. This is not to say that those labels are redundant. Furthermore, the frequently used product and food labels are in these studies reported to have gained a high trustworthiness among the Nordic consumers. Consequently, the predominant picture is that Nordic consumers are well aware of the major labels for products, services, and food, that they have a fair understanding of the meanings of the labels, and that they are considered as being trustworthy. The trend is that the recognition, knowledge, and confidence of the labels have increased over the years.

However, there is a somewhat contradictive picture regarding consumer perceptions and knowledge of the eco-labels. A recurring theme is individual confusion on the meaning of all symbols in the rich flora of label, logos and brands. These conclusions stem mainly from quantitative studies, such as focus group interviews and group interviews that examine consumers' deeper knowledge of the labels. The knowledge shortage and following confusion is mainly related to particularly organisational and informational issues. Organisational issues mean, for example, the importance of the different organisations behind the schemes. The informational issues regard what the labels actually promise and what differentiates labelled products from non-labelled ones. The many eco-labels frequently confuse consumers who are not sure of the different meanings. The shortage of knowledge and confusion may also be the reason for the consumer distrust in eco-labels that is reported in these studies. Instead, some consumers regard the labels as market gimmicks and say that all products are basically the same or that environmentally friendly products do not function as well as others. The confusion is judged as a major obstacle, as consumers rather tend to avoid the information and use the confusion as a justification for not buying labelled products. As a consequence, if they should be expected to use them, consumers have a need for improved knowledge on what the various labels actually mean.

The two abovementioned strands of results and conclusions are somewhat inconsistent. On one hand, a number of studies report on recognition, knowledge and trust, on the other, other studies claim there is a lack of knowledge and distrust leading to consumers avoiding labels. The conclusion is that the issue is a matter of level of knowledge that consumers need to reach. The basic knowledge most consumers are reported to have should be sufficient as the concept of eco-labelling builds on simplicity for the user, i.e. that it is enough to know that labelled products are supposed to be better than the 
average product. Regarding the relatively low level of involvement in green consumption, which most consumers seem to admit, it is likely that there are only a small number of individuals who have actually put efforts into analysing the backgrounds of the schemes. In other words, it is probable that the knowledge problem is overemphasised.

At a first glance it would be reasonable to apply an explanation to the inconsistency in a fashion similar to the abovementioned. However, there could be additional factors contributing to the situation, which may be more important to consider, because lack of trust is a separate issue to depth of knowledge. Unfortunately the studies do not provide any other clues besides that insufficient information raise new and unanswered questions, which in turn result in distrust. An additional sensible explanation may be a general attitude towards new obligations; it is not enough to find the desired product at lowest price, one should also consider the environment and other secondary factors. Regardless of reason, it is unfortunate that individuals are left without the background information for the labelling schemes.

\section{Information wanted: simple symbols or written text and sufficiency of environmental information}

The findings on what kind of information that the consumers want and how extensive this information should be are also somewhat inconsistent. A number of studies examine how consumers would prefer to have the information presented. These studies both report that most consumers express interest in information on how products relate to environmental, ethical, and health issues. It is also concluded that most consumers appreciate the simplicity of logotypes as information carriers for most products. Contrary to this, there are also studies, mainly carried out as qualitative focus group interviews, reporting that a number of consumers find the simple symbols insufficient and would like to obtain more information, which cannot be provided through simple labels. In particular, some consumers criticise that they cannot read from a label how the performance of a labelled product is superior in relation to non-labelled products, and what aspects that are regarded. These studies often propose expanded text information or declarations explaining the environmental features of the products to meet the voiced consumer demand of more information. However, none of these studies discuss in detail what information that should be included or how it should be presented.

Whereas studies in all Nordic countries report that consumers are apparently claiming that there is too little or insufficient environmental information and request additional information, a number of studies find that consumers state there is enough or even an overwhelming amount of information available, in which case the consumers ask for guidance. In addition, the studies on perceptions and understanding of environmental product declarations are distinct in the message that consumers can hardly understand complex declarations. Therefore, the conclusion tends to be that the simple information carriers, such as eco-labels, are sufficient for most consumers.

\section{Trustworthy information is the key}

On one hand, an eco-label calls for attention to the product's environmental properties and as such is effective in influencing consumers. One the other hand, some studies indicate that producers can get away with any type of environmental information, i.e. that presence of environmental information as such gives credibility. The great number of available labels is proposed as one reason for the confusion and uncertainty among 
consumers that is reported in some studies. It is not possible for every consumer to know all labels and underlying schemes.

A clear message from most studies conducted in the Nordic countries is, however, that consumer trust in the information is a prerequisite if it should be successfully used, regardless if the information is conveyed as a label, graphic representation or as text. Trust may even be the determinant factor for paying attention and using environmental product information. Whether the state or a consumer or environmental organisation does the verification/certification is less important as long as it is conducted by a reliable and unbiased third-party. Weak trust is repeatedly mentioned as a main reason for not using the information in the purchase situations. Also consumers requesting more written and explanatory information claim to prefer eco-labels if the alternative information is not controlled.

While the major environmental and food labels are considered trustworthy and thereby accepted by many consumers, companies' own information and information with uncertain origin is considered less reliable.

\section{Environmental literacy and the perception of "green products"}

A few studies have investigated environmental literacy of consumers in general and in relation to impacts caused by products and consumption. The concept of environmentally sound products is reported to be problematic for many consumers. Despite the limited number of studies, conclusions point towards general difficulties in explaining environmental problems related to the products, what distinguishes "green products" from conventional products or what the actual benefits of a supposed superior or eco-labelled product are. On the other hand it was also demonstrated that the link between environmental literacy and preferences for purchasing environmentally benign products is rather weak. It seems for instance that many consumers who appreciate and use product related environmental information do not differentiate between information on environmental, health and safety issues but rather view them holistically as an additional quality of the products. They perceive the terms synonymously and expect that products with good environmental aspects are safe and sound.

\subsection{Use of environmental product information}

Using environmental product information implies that consumers let the information guide their purchase decisions regardless of the resulting product selection, meaning that a consumer can also choose not to buy the product that is most environmentally sound. This is because the environmental aspect is only one among many purchasing criteria, and because consumers have different grounds for buying different products.

For using the information, consumers must observe or read it. In other words, the term use has proven to relate to various activities in the purchasing process, such as:

- Reading the information;

- Discussing the information;

- Considering the information in the decision making process;

- Making a product choice. 


\section{Discrepancy between intention and behaviour}

The main indication from the studies is, however, that most consumers have a positive attitude towards the green labels and environmentally benign products in general. Consumers respond that they look for and purchase labelled products. A number of studies also find that a substantial share of the consumers claim that they are willing to pay a price premium for labelled or environmentally friendly products. Typically, they are willing to pay approximately $10 \%$ more. On the other hand, some state that environmentally friendly products should not cost more. It is also reported that Danish consumers actually were willing to pay $10 \%$ to $17 \%$ more for eco-labelled paper and that the sales of eco-labelled washing detergent most likely would drop by $6 \%$ if the label was dropped (Juhl \& Poulsen, 2002).

However, a number of reports build on the statement that the green product market has not developed as desired and investigate why consumers are not acting according to their attitudes, i.e. they do not purchase labelled or environmentally benign products to the extent they indicate or insinuate when asked. There are studies from all Nordic countries trying to explain the discrepancy between intentions and actual behaviour.

Some of the explanations, like lack of trust in the information, overwhelming information, lack of time to search for it, difficulties in interpreting information and attitudes such as considering eco-products as lower quality and more expensive have already been mentioned. A few studies from all Nordic countries which have further investigated the discrepancy add knowledge to the abovementioned ones.

Furthermore, the actual users of product related environmental information are to be found in the group of consumers who strongly prioritise the environmental quality issues they perceive as related to products. The studies imply that most consumers do not have such strong preferences and, therefore, do not spend the necessary additional time and efforts to find these products. They implicitly point at trade-offs between time, stress, price, appearance, and quality in the purchase situation. However, habits and routine are also important factors as consumers do not abandon a brand or product they are familiar with in favour of unknown but labelled products.

In addition, some results indicate that consumers tend to prioritise "green products" when they perceive that the environmental qualities are more strongly related to themselves, for instance health issues due to organic food production or chemicals in textile production in relation to global warming as a consequence of energy use.

\subsection{Main conclusions from the analysis of the literature}

Currently, short and simple information systems controlled by a third party, i.e. ecolabels, seem to be preferred by most consumers. Most likely, this means that extensive qualitative and/or qualitative Environmental Product Declarations may be of most relevance for a few private consumers. However, simplified and controlled declarations may serve as a complement to eco-labels.

It appears like there is a potential to increase the share of consumers using environmental product information/eco-labels. This conclusion is built on the findings that most consumers seem to recognise and trust the main eco-labels. Furthermore, consumers in general consider environmentally benign products important, that consumers are positive towards eco-labels, and many studies conclude that consumers claim to purchase more green products than they actually do. There are indications that 
environmental awareness, rather than environmental literacy, triggers the use of ecolabels. In addition, the green consumer segments appear to be larger than the current market seems to be, with reservations for the limited knowledge of its size. However, it is not possible to quantify this potential.

Neither does the current knowledge base suggest any tools for the realisation of the potential. However, the majority of up-to-date consumer surveys seem to capture the attitudes and intentions from citizen-interviewees rather than from consumerinterviewees, because the interviews take place in situations distant from the purchase situations. Furthermore, these studies have a tendency to aggregate statistically average situations, implying that the consumers follow regular behaviour patterns. The answers on why individuals do not use environmental product information/choose eco-labelled products, however, bring to light different behaviour and actions in different situations. These situations may be influenced by available time and money, external stimuli like campaigns and information, the availability of eco-labelled products, trust in the information provided and probably also motivation and understanding of the relevance of different product choices. As a consequence, it is important that interviews conducted in order to understand the actual preferences and factors influencing the purchase criteria take place closer to the purchase situations, i.e. in the shops. 


\section{Identified knowledge gaps and proposals for further studies}

The previous section has mapped out and extracted a picture of the current Nordic knowledge base on consumer perceptions, understanding and use of product related environmental information. As a result, the knowledge gaps have clarified and are sketched in the following section. Some of these gaps are suitable for research while others may be more suitable as development projects for identified actors. The suggestions follow the structure overleaf: 
- Labelling

- Factors influencing trust/distrust in the environmental relevance of labels, the organisational and administrative bodies.

○ Evaluation models and feedback mechanisms.

- The role of shop display and sales personnel to stimulate the demand for environmentally benign products.

- Environmental claims

- Current use and trends in the use of claims.

- Consumer perceptions of meaning and trustworthiness.

- Producer rationale for using environmental claims.

- Market impacts.

○ Relevance of the claims - justification.

- Environmental declarations

○ Perceptions, understanding and use among:

- Consumers,

- Professional purchasers.

○ How to guide and simplify the use of information.

- Size of green product market

- Educational attributes of environmental product information

- Product perspective - how consumers perceive and select products from an environmental perspective

- How consumers view the environmental performance of non-labelled products.

○ How to evaluate and make reflected choices without eco-labels.

- Dynamics of factors influencing the purchase situation

- Why consumers choose and do not choose environmentally sound/ecolabelled products in different purchase situations.

○ Purchasing criteria for different product groups 


\section{Labelling}

The knowledge of the positive side of eco-labels is largely investigated and described. The results serve as rationale for studies on how the labels could be further utilised. Despite the documented high recognition and trustworthiness there is also negative attitudes and distrust among some consumers. In general, the distrust is explained by insufficient information on multiple versions: how schemes are organised, who stands behind them, the environmental relevance of the product group and in what ways labelled products are superior to conventional ones. There is a potential joint interest for both operators of eco-labelling schemes and the research community to identify suitable paths for conveying this secondary information to interested consumers. The consumers who request complementary text or explanations seem to be unwilling to learn more about the meaning of a label by, for example, looking up the criteria documents. It is therefore relevant to highlight potential ways to complement labels and symbols with explanatory texts or aides.

The labels would, in the long run, be in a stronger position if they did not entirely have to rely on general environmental awareness of consumers and altruistic feelings for the environment. An alternative approach to identify ways to increase consumer motivation to buy green products would be to develop evaluation models for the estimation of environmental benefits of a market shift towards eco-labelled products. The model should also include feedback mechanisms to the consumers, something that was judged as needed according to the key people contacted in this study. The issue of actual environmental benefits due to choosing labelled products would probably influence the attitude and trust in the systems.

A limited number of studies cover the role of sales staff and retailers in the process of supporting the environmentally conscious consumers. They appear to serve as ecological gatekeepers. The studies indicate, however, that sales personnel have limited knowledge about eco-labels, but that they could be able guide consumers to environmentally sounder purchases if they are provided with the appropriate information. These issues deserve further research.

Just as the shop staff could play an important role for consumer choice of products, the shops' display of eco-labels, environmentally benign products and information provision about these products may also be important. The shop-shelf can be considered as a leverage point for most consumers. Nevertheless, no studies were found on the role of display in the shops from that perspective. It would be interesting to compare and benchmark different displays in order to find potential in and recommendations for influencing the demand of green products.

\section{Environmental claims}

Environmental marketing and particular self-declared claims of producers are sometimes mentioned as alternative or complementary to eco-labels, at least in product groups where labelling is not suitable. Therefore, it is possible to see an increase in use of these claims in the future. However, the phenomenon is poorly researched in terms of its current function and use. It is also relevant to investigate how consumers perceive claims in terms of understanding the messages, their environmental relevance and, not least, their credibility. Similarly, it would be useful to understand the producers' drive and perceptions of market impacts. 
As the relevance of these claims is regulated by both an international standard (ISO 14021) and consumer protection legislation, it is important to gain a better understanding of how the control mechanism works in practice and how producers justify their claims.

\section{Environmental declarations}

The environmental declarations are in increase and they are sometimes applied as a substitute to other information systems. The declarations need, therefore, to be better understood. As a first iteration, specific studies on how consumers and professional buyers perceive, understand and use them would be useful. Producers that provide environmental declarations should also be asked how their perceptions of how the declarations should be used.

Moreover, product declarations may have a possibility to be useful in the market, especially for buyers who are obliged to consider environmental aspects of products, for the use in the supply chain for aggregation purposes or for product groups of more complex/high involvement products. The processing of this type of information is, however, difficult among both consumers and professional buyers, mainly because the information is supposed to come without any assessment of the product's environmental performance. The need for transparent guides, codes or interpretation tools is clear among the studies in the literature review.

\section{Size of green product market}

The literature review showed examples on studies that compare stated use of eco-labels and a perceived impression of the market for eco-labelled or "green products" by consumers. The picture of the green market and how it has developed in terms of various product groups - success stories and failures - is not clear. It is possible to find anecdotal figures and other evidence of its existence but the full picture is still lacking in public reports. This information would furthermore be useful background material to comparative studies on consumer intentions and actions. Apparently there are expectations that the market forces should drive an increase in the supply of environmentally benign products. However, considering the small number of product groups that actually can be eco-labelled and the size of the segment of environmentally devoted consumers, the potential share cannot be that substantial.

\section{The educational attribute of environmental product information}

A frequently mentioned secondary effect from product specific environmental information and eco-labels is that it reminds consumers of the environmental dimension of production and consumption. The information is claimed to serve both as an awareness raiser and fact provider. The educational attribute is however often claimed but poorly researched. On the other hand, the environmental knowledge is supposed to be an important precondition for using environmental product information. There is a general lack of knowledge on which channels appeal and lead to increased awareness and knowledge among consumers.

\section{Product perspective - how consumers perceive and select products from environmental perspective}

Most studies found in the literature review take a starting point in labelling or declaration schemes rather than in products. The approach brings a number of 
interesting findings. However, most product groups are not open for eco-labelling or lack environmental information. There are indications that a portion of consumers is considering these products to be free from environmental impacts.

Investigations starting from product groups open up new questions such as how consumers perceive the environmental relevance of products, what type of environmental information they would find useful and how they would judge this information in a purchase situation. In the discussion with the key people it was mentioned that the environmental aspects of a product are not yet well established in the minds of consumers. A clarification of the environmental relevance would assist consumers to build a framework to deal with environmental impacts of products.

The purpose would also be to explore potential triggers for environmental considerations among consumers for products with or without sparse environmental information. An aim could be to find complementary information systems for product groups not suitable for labelling.

\section{Factors influencing the purchase situation - the dynamics of factors influencing consumers}

The link between intention and action is obscure and the empirical evidence on whether consumers actually use their labels for product selection is limited. Many aspects influence why and when consumers pay attention to green products and use environmental information in the purchasing selection. Consumer surveys are mostly done with consumers outside their consumer role, i.e. as individual citizens. As such, consumer segmentations and attitude investigations can appear somewhat static. The picture of patterns of the green purchases is however more like a moving target, which is difficult to capture in any one snapshot. It is apparently useful to concentrate research closer to the purchasing situation. This has been done in a comprehensive study on food labelling (Hansen \& Mörch Marckmann, 2001) in which interviews and inquiries into consumer rationale, at the time of the purchase. The next study in the research project was consequently based on in-situ interviews in combinations with a follow up survey (Hansen, Knudsen \& Holm, 2001). Most likely, this approach has resulted in a picture that better depicts a consumer in his or her role as a consumer.

The aggregate picture, which includes the many factors that influence consumer use of environmental information is complex, multifaceted and most importantly, dynamic. The determinant factors can vary between occasions. Moreover, many factors are beyond consumers' awareness. This indicates that environmental product information cannot carry the sole responsibility of greening the market. It also indicates that a higher understanding of contextual factors can facilitate the understanding of consumers and environmental information.

Based on customer segmentation we can conclude that as there is still a great number of individuals who are not perceptive to environmental properties of the products and thus are not likely to be interested in environmental product information. In the segmentation studies, the actual share of consumers that to some extent give priority to environmentally related properties of the products they purchase is in the magnitude of $20 \%$ to $50 \%$. This may indicate current limitations of informative policy instruments and environmental product information, as they probably have little or no impact outside the greener consumer segments. A great potential lies in understanding factors 
that, according to the segmentation model, would imply fluctuation of individuals between consumer segments.

From the literature reviews there are indications that purchasing criteria vary between product groups, such as every day commodities and durable white goods. A more detailed comparison of purchasing criteria in terms of different types of product groups and also type of consumers can prove useful to identify the potential products that can get increased environmental relevance in the eyes of consumers. A longer-term study on purchasing criteria for different products groups could also illustrate how and if the environmental product aspects are becoming a part of general product quality.

In summary, coming to an early halt in the investigations on how consumers and green information function in the market can lead to an over-simplified picture. In fact, the simple picture, which contains consumer types, information types and purchasing criteria, is usually the common denominator among research projects. Below the surface there are, however, more interesting findings which bear more resemblance to the market complexity that sets the scene for consumer perception, understanding and use of environmental product information. 


\section{Reference list}

Alarik, O. (2002). Kunskapsöversikt: Ekologiska livsmedel ur konsumentperspektiv. Rapport 2002:4. Swedish Consumer Agency. Stockholm.

Armila, M. \& Kähkönen, N. (1997). The purchase decision making process of an environmentally conscious consumer: Information search and alternative evaluation. Helsinki School of Economics and Business Administration.

Arvola, A., Biel, A., Grankvist, G., Koivisto-Hursti, U-K., Larsson, M., Magnusson, M., Sjödén, P-O. (2000). Ekologiska livsmedel: Konsumenternas attityder, vanor och värderingar. Mat21 Research Program.

Asikainen, J. (2000). Environmental labeling as means to affect consumer choices: Case of Nordic Swan. Helsinki School of Economics and Business Administration.

Björk, P. (1997). The effect on green labels on consumer decision making. Swedish School of Economics and Business Administration.

Bjørner, T. Bue, Gårn Hansen, L., Russel, C. S., Olsen, T. (2002). The effect of the Nordic Swan Label on consumers' choice. AKF-Förlaget. Copenhagen.

Carlsson-Kanyama, A., Eriksson, B., Henriksson, G. (2001). Stakeholders and consumption in the five cities. Swedish national report, ToolSust Program.

Edlund, S., Leire, C., Thidell, Å. (2002). Svanens roll $i$ förhållande till andra miljöinformationssystem och miljöledning. TemaNord 2002:517. Nordic Council of Ministers. Copenhagen.

Erhvervsministeriet (1999). Moerkning: Morkningsudvalgets redegørelse. The Danish Consumer Agency. Copenhagen.

Ernhult, T.,Kollberg, M. (2002). Hur värderar bostadsmarknadens slutkonsumenter miljöanpassade alternativ. Royal Technical Institute. Stockholm.

Fallenius, F., Sjöstedt, C., Solér, C. (1997). Rekommendationer för kommunikation av miljömärkning Typ III inom ramen för ISO 14000. Gothenburg Research Institute.

Hansen, P. J., Knudsen, P. E., Holm, A. (2001). Forbrugernes krav til fodevarumärkning og vareinformation: A Pan-Nordic study of consumer behavior and attitudes towards food labeling. TemaNord 2001: 573. Nordic Council of Ministers. Copenhagen. 
Hansen, P. J., Mörch Marckmann, B. (2001). Forbrugernes brug af födevaremärkning. Del 1. Litteratur- og pilotstudie. TemaNord 2001:525. Nordic Council of Ministers. Copenhagen.

Heiskanen, E. \& Timonen, P. (1995a). Consumption, knowledge, attitudes and environmental policy. National Consumer Research Centre. Helsinki.

Heiskanen, E. \& Timonen, P. (1995b). Environmental information and consumer choice. Working paper 18. National Consumer Research Centre. Helsinki.

Heiskanen, E. \& Timonen, P. (1996). Environmental information and consumer decisions: Final report: Consumers' needs for environmental information. Publication 9. National Consumer Research Centre. Helsinki.

Heiskanen, E., Kärnä, A., Niva, M., Timonen, P., Munck af Rosenschöld, E., Pripp, L., Thidell, Å. (1998). Environmental improvements in Products Chains. TemaNord 1998:546. Nordic Council of Ministers. Copenhagen.

Himmelstrup Dahl, E., Hjort T. (2002). Indragelse af miljøhensyn ved indkøb og design af tekstilprodukter: Interviews af designere og indkøbere. Danish Environmental Protection Agency. Copenhagen.

Holmberg, H-E. (1999). Konsumentundersökning om ekologiska produkter/krav. KRAV and LRF.

Jensen, M. L., Sörensen, S. Y., Schmidt, A, Grinderslev, M. Hjelmar, U (2002). Forbrugernes muligheder og interesse for køb af grøn elektronik. Danish Environmental Protection Agency. Copenhagen.

Jönsson, K. (2000). Communicating the environmental characteristics of products: The use of environmental product declarations in the building, energy and automotive industries. IIIEE dissertation 2000:5. IIIEE, Lund University.

Juhl, H. J., Poulsen C. S., (2002). Den forbrugerbaserede vaerdi af en märkning: Med fokus på svanemärket. Aarhus School of Business.

Kanerva, T \& Timonen, P. (1999). Labels: product information for the consumer? Publication 8. National Consumer Research Centre. Helsinki.

Kiljunen, P. (1998). Environmental grading of electricity. Study on public opinion. Finnish Energy Industries Federation - FINERGY. Study report No. 6. Yhdyskuntatutkimus Oy.

Kogg, B., Thidell, Å. (2003). Utvärdering av system för egendeklarationer av farliga kemiska ämnen i varor: Exempel från Byggsektorn och Textilindustrin. National Chemicals Inspectorate. Stockholm.

Konsumentverket (1995/96). Konsumenten och miljön: Resultat från en undersökning av svensk konsumenters miljömedvetenhet. Rapport 1995/96:13. Swedish Consumer Agency. Stockholm 
Konsumentverket (1998). Allmänhetens kunskap, attityder och agerande i miljöfrågor. Rapport 1998:7. Swedish Consumer Agency. Stockholm.

Konsumentverket (2001). Mitt hem är ingen sopstation... och andra tankar konsumtion och miljö. Rapport 2001:11. Swedish Consumer Agency. Stockholm.

Kuluttajavirasto (1997). Opinio -97, Kuluttajaviraston selvitys kuluttajien mielipiteistä (Investigation of the public opinions by the consumer agency). Taloustutkimus Oy.

Kuusela, H. (1995). Energy Conservation and Consumer decision-making. Linkki. Publication 8. Research program on consumer habits and energy conservation.

Kuusela, H. (1996). Factors affecting the acquisition of domestic appliances and energy saving. Linkki. Publication 13. Research program on consumer habits and energy conservation.

Laaksonen, P. \& Mäntylä, M. (2000). The concept of environmental friendliness: A Comparison of consumer and expert views. Publication 5. National Consumer Research Centre. Helsinki.

Landsvirkjun (The National Power Company) (2001). Umhverfisvitund: Viðhorfsrannsókn, (Environmental awareness: Attitude survey). Performed by Gallup.

Methi, N., Stø, E., Throne-Holst, H., Vittersø, G. (2001). Consumption and environment in Fredrikstad. Norwegian national report, ToolSust Program.

Munck af Rosenschöld, E., Pripp, L. et al. (1996). Utredning angående miljövarudeklarationer. IIIEE, Lund University.

Neergaard, P., Andersen, M., Bech, L. (2002). Environmental-friendly textiles. Copenhagen Business School.

Niva, M., Heiskanen, E \& Timonen, P. (1996). Environmental information in consumer decision making. Publication 11. National Consumer Research Centre. Helsinki.

Nordisk Miljömärkning (2002). The Nordic Swan Label. Taloustutkimus Oy.

Palm, L., Jarlbro, G. (1999). Nordiska konsumenter om Svanen: livsstil, kännedom, attityd och förtroende. TemaNord 1999:592. Nordic Council of Ministers. Copenhagen.

Palm, L., Windahl, S. (1998a). Relevant och begriplig miljöinformation: Metodstudie. Rapport 1998:19. Swedish Consumer Agency. Stockholm.

Palm, L., Windahl, S. (1998b). How Swedish consumers interpret and use environmental information. Rapport 1998:28. Swedish Consumer Agency. Stockholm. 
Puttonen, J. \& Wennerström, P. (2001). Study on consumers' energy conservation 2001. Motiva Oy, Taloustutkimus Oy.

SFS-Ympäristömerkintä (2001). The level of awareness of the Nordic environmental label (Pohjoismaisen ympäristömerkin tunnettuus). Taloustutkimus Oy, Omnibus maaliskuu.

Solér, C. (2001). Communication of product related environmental information. User reequirement studies of Environmental Product Declaration, EPD, systems. NIMBUS Project. CPM Report 2001:4. Chalmers Institute of Technology.

Spilling, J. (1999). Holdninger til miljöspörsmål i sykehussektoren med spesiell vekt på anskaffelse av medisinsk förbruksutstyr. Burson-Marsteller A/S.

Statens offentliga utredningar (1999). Märk väl! Betänkandet av utredningen gällande konsumentinformation om dagligvaror. SOU 1999:7. Statens Offentliga Utredningar. Stockholm.

Strandbakken, P. (2001). Environmental product information schemes (EPIS) in Norway. National Institute for Consumer Research (SIFO). Oslo.

Strandbakken, P., Stø, E. (2002). Advantages and limitations of eco-labels as consumer and environmental political instruments. DEEP. National Report. National Institute for Consumer Research (SIFO). Oslo.

Szatek, A. (2001). Vägen till Marknaden. LUI.

Szatek, A. (2003). Den svenska modellen: En studie bland svenska konsumenter. LRF.

Thøgersen, J. (2000). Psychological determinants of paying attention to eco-labels in purchase decisions: Model development and multinational validation. Journal of Consumer Policy, 23, 285-313.

Tiilikainen, A. (1996). Dimensions of Environmentally-sound foodstuffs: Qualitative study of consumer's perceptions. Monistesarja Nr. 10. University of Helsinki.

Timonen, P., Heiskanen, E, Kärnä, A \& Niva, M. (1998). Improving the environmental quality of products: the views of actors in the product chain. Publication 1. National Consumer Research Centre. Helsinki.

Torjusen, H., Nyberg, A., Wandel, M. (1999). Økologisk produsiert mat: forbrukernes vurderinger og bruksmønster: En spørreundersøkelse fra Stange- og Hamarområdet. Report nr. 5 - 1999. National Institute for Consumer Research (SIFO). Oslo.

Tufte, P-A. (1997). Helse- og Miljømerking av produkter. En studie av forbrukernes oppfatninger om produktmerking av miljövarefakta. Report nr. 6 -1997. National Institute for Consumer Research (SIFO). Oslo.

Tufte, P-A., Lavik, R. (1997). Helse- og Miljøinformasion. Report nr. 4 - 1997. National Institute for Consumer Research (SIFO). Oslo. 
Unger, T. (2002). Gennemskuelighed og tillid mellem landmoend og forbrugere $i$ Landbrugslauget: Delprojekt 1. Karakteristika for forbrugerandelshaverne. Direktoratet for FødevareErhverv. Copenhagen.

Vanninen, M. \& Viinikainen, H..(1995). The Nordic environmental label. Consumer research study. Finnish Consumer Agency. Mikkeli Provincial State office, Consumer Project. Mikkeli Polytechnic, Institute of Business.

Winward, J., Schiellerup, P. \& Boardman, B. (1998). Cool Labels: The first years of the European Energy Label. University of Oxford.

Internet sources

Methi, N. (2000). Tenker ikke miljø når vi handler. Forbrukerrådet. Available: http://forbrukerportalen.no/Artikler/forbrukerrapporten/2000/1023903397.32. [05.12.2000]

Miljøstyrelsen (2001). Evaluation of the Eco-label Promotion Campaign. Available: http://www.mst.dk/news/05010000.htm. [09.10.2002]

Naturvårdsverket (2003). Hur ökar vi efterfrågan på gröna produkter. Available: http://www.naturvardsverket.se/dokument/hallbar/ipp/efterfragan/fragan.htm\#m arkning [05.13.2003]

SFS-ympäristömerkintä (1998). "Jo yli 90 prosenttia tuntee joutsenmerkin" (“Already over $90 \%$ of the people knows the Swan"). SFS. Available: http://www.sfs.fi/ymparist/index.html

\section{Contacted persons}

The following persons where contacted for discussion or guidance to persons or literature suggestions.

Anders Biel, Gothenburg University, Sweden

Anna Margrét Jónsdóttir, Quality and Assurance Manager, Hagkaup, Iceland

Anna Wahlberg, Svenskt Sigill, Sweden

Anna-Lisa Lindén, Sociologiska Institutionen Lunds universitet, Sweden

Bente Halkier, Institut for Miljö, Teknologi og Samfund, Denmark

Björn Gunnarsson, Environmental Research Institute, University of Iceland

Björn-Erik Lönn, Nordisk Miljömärkning, Norway

Brynhildur Pétursdóttir, Consumers Association of Iceland, Iceland

Cecilia Solér, Handelshögskolan Göteborg, Sweden

Claus Egeris Nielsen, Forbrugerstyrelsen, Denmark

Eivind Stø, SIFO, Norway

Guðjón Jónsson, VSO Consulting, Iceland

Gunnar Vittesö, SIFO, Norway 
Gunne Grankvist, Psykologiska Institutionen, Göteborgs universitet, Sweden

Helena Ågren, Naturvårdsverket, Sweden

Hulda Steingrímsdóttir, Local Agenda 21 in Hafnarfjörður Town, Iceland

Jóhannes Gunnarsson, Consumers Association of Iceland

Jörn Toldstedt, dk-Teknik Energi \& Miljö, Denmark

Lars Jonsson, SIS, Sweden

Lars Palm, Medie- och Kommunikationsvetenskap, Lund University, Sweden

Leena Nyqvist-Kuusola, SFS Ecolabelling, Finland

Louise Ungerth, Konsumentföreningen, Sweden

Maria K. Magnusson, Institutet för folkhälso- och vårdvetenskap, Uppsala universitet, Sweden

Mikael Klintman, Sociologiska institutionen, Lunds universitet, Sweden

Per Lögdlund, MERA, Sweden

Ragnar Unge, SIS, Sweden

Richard Hansson, GfK Sverige, Sweden

Sigrún Guðmundsdóttir, Ecolabelling Board in Iceland

Sören Askegaard, Institute for Marketing Odense, Denmark

Stefán Gíslason, National Association of Local Authorities in Iceland, Iceland

Porvarður Árnason, Ethical Research Institute, University of Iceland, Iceland 


\section{Appendix}

\section{Collection of literature sources used as basis for the review}

\begin{tabular}{|c|c|c|c|c|}
\hline $\begin{array}{l}\text { Publ. } \\
\text { year }\end{array}$ & Title & Author/s & $\begin{array}{l}\text { Publishing } \\
\text { organization }\end{array}$ & $\begin{array}{l}\text { Executive } \\
\text { organisation }\end{array}$ \\
\hline 1995 & $\begin{array}{l}\text { Consumption, knowledge, } \\
\text { attitudes and environmental policy. }\end{array}$ & $\begin{array}{l}\text { Eva Heiskanen, } \\
\text { Päivi Timonen }\end{array}$ & $\begin{array}{l}\text { National } \\
\text { Consumer } \\
\text { Research Centre, } \\
\text { Finland }\end{array}$ & \\
\hline 1995 & $\begin{array}{l}\text { Konsumenten och Miljön - } \\
\text { Resultat från en undersökning av } \\
\text { svenska konsumenters } \\
\text { miljömedvetenhet }\end{array}$ & & $\begin{array}{l}\text { Konsumentverket, } \\
\text { Sweden }\end{array}$ & $\begin{array}{l}\text { Eureka Research, } \\
\text { The Roper } \\
\text { Organization }\end{array}$ \\
\hline 1995 & $\begin{array}{l}\text { Forbrugeradfärdsundersøgelser } \\
\text { med miljømässigt sigte }\end{array}$ & John Thøgersen & MST, Denmark & MST DK \\
\hline 1995 & $\begin{array}{l}\text { Oslo Ministerial Roundtable - } \\
\text { conference on sustainable } \\
\text { production and consumption }\end{array}$ & & $\begin{array}{l}\text { Miljöverndeparte } \\
\text { mentet, Norway }\end{array}$ & Symposium \\
\hline 1995 & $\begin{array}{l}\text { Environmental information and } \\
\text { consumer choice }\end{array}$ & $\begin{array}{l}\text { Eva Heiskanen, } \\
\text { Päivi Timonen }\end{array}$ & $\begin{array}{l}\text { National } \\
\text { Consumer } \\
\text { Research Centre, } \\
\text { Finland }\end{array}$ & \\
\hline 1995 & $\begin{array}{l}\text { Energy Conservation and } \\
\text { Consumer decision-making }\end{array}$ & Kuusela, Hannu & $\begin{array}{l}\text { Linkki. Research } \\
\text { program on } \\
\text { consumer habits } \\
\text { and energy } \\
\text { conservation, } \\
\text { Finland }\end{array}$ & \\
\hline 1995 & The Nordic environmental label & $\begin{array}{l}\text { Vanninen, Marko } \\
\text { \& Viinikainen, } \\
\text { Harri }\end{array}$ & $\begin{array}{l}\text { Finnish Consumer } \\
\text { Agency. Mikkeli } \\
\text { Provincial State } \\
\text { Office, Consumer } \\
\text { Project. Mikkeli } \\
\text { Polytechnic, } \\
\text { Institute of } \\
\text { Business, Finland }\end{array}$ & \\
\hline 1995 & $\begin{array}{l}\text { Product policy and the } \\
\text { environment: the examples of eco- }\end{array}$ & Frieder Rubik & IÖW, Germany & \\
\hline
\end{tabular}




\begin{tabular}{|c|c|c|c|c|}
\hline & labels & & & \\
\hline $\begin{array}{l}1995 / 9 \\
6\end{array}$ & $\begin{array}{l}\text { Konsumenten och Miljön - } \\
\text { Resultat från en undersökning av } \\
\text { svenska konsumenters } \\
\text { miljömedvetenhet }\end{array}$ & & $\begin{array}{l}\text { Konsumentverket, } \\
\text { Sweden }\end{array}$ & $\begin{array}{l}\text { The Roper } \\
\text { Organization and } \\
\mathrm{KO}\end{array}$ \\
\hline 1996 & $\begin{array}{l}\text { Environmental information and } \\
\text { consumer decisions: Final report: } \\
\text { Consumers' needs for } \\
\text { environmental information }\end{array}$ & $\begin{array}{l}\text { Eva Heiskanen, } \\
\text { Päivi Timonen, } \\
\text { Mari Niva }\end{array}$ & $\begin{array}{l}\text { National } \\
\text { Consumer } \\
\text { Research Centre, } \\
\text { Finland }\end{array}$ & \\
\hline 1996 & $\begin{array}{l}\text { Utredning angående } \\
\text { miljövarudeklarationer }\end{array}$ & $\begin{array}{l}\text { Elisabeth Munck } \\
\text { af Rosenschöld, } \\
\text { Lena Pripp }\end{array}$ & $\begin{array}{l}\text { IIIEE at Lund } \\
\text { University }\end{array}$ & $\begin{array}{l}\text { IIIEE at Lund } \\
\text { University }\end{array}$ \\
\hline 1996 & $\begin{array}{l}\text { Environmental information in } \\
\text { consumer decision making }\end{array}$ & $\begin{array}{l}\text { Niva, Mari; } \\
\text { Heiskanen, Eva \& } \\
\text { Timonen, Päivi }\end{array}$ & $\begin{array}{l}\text { National } \\
\text { Consumer } \\
\text { Research Centre, } \\
\text { Finland }\end{array}$ & \\
\hline 1996 & $\begin{array}{l}\text { Miljømärking og } \\
\text { miljømarkedsføring af tøj i } \\
\text { Danmark }\end{array}$ & John Nordbo & \begin{tabular}{|l|} 
Miljö- og \\
Energiministeriet \\
Miljöstyrelsen, \\
Danmark
\end{tabular} & $\begin{array}{l}\text { Center för } \\
\text { alternativ } \\
\text { samfundsanalys }\end{array}$ \\
\hline 1996 & $\begin{array}{l}\text { Environmental labelling - a tool } \\
\text { for communicating environmental } \\
\text { performance }\end{array}$ & Fredrik Orre & $\begin{array}{l}\text { Electrolux, } \\
\text { Sweden }\end{array}$ & $\begin{array}{l}\text { C-N } \\
\text { Environmental } \\
\text { Affairs }\end{array}$ \\
\hline 1996 & $\begin{array}{l}\text { Hvordan kan miljöatfärd } \\
\text { förklares? En studie av } \\
\text { tidsperspektiv og miljörelaterte } \\
\text { holdninger som prediktorer för } \\
\text { miljöatfärd. From the compendium } \\
\text { "Faglig mangfold - nyttig } \\
\text { kunnskap" }\end{array}$ & $\begin{array}{l}\text { Wibecke Brun } \\
\text { (article author) } \\
\text { Einar Strumse } \\
\text { (book editor) }\end{array}$ & $\begin{array}{l}\text { Norges } \\
\text { forskningsråd, } \\
\text { Norway }\end{array}$ & $\begin{array}{l}\text { Hemil Senteret, } \\
\text { Bergen University }\end{array}$ \\
\hline 1996 & $\begin{array}{l}\text { Biff och Bil? - om hushållens } \\
\text { miljöval }\end{array}$ & & $\begin{array}{l}\text { Naturvårdsverket, } \\
\text { Sweden }\end{array}$ & $\begin{array}{l}\text { Forskargrupp at } \\
\text { FAO }\end{array}$ \\
\hline 1996 & $\begin{array}{l}\text { Environmental information and } \\
\text { consumer decisions. Final report: } \\
\text { Consumers' need for } \\
\text { environmental information }\end{array}$ & $\begin{array}{l}\text { Eva Heiskanen, } \\
\text { Päivi Timonen }\end{array}$ & & \\
\hline 1996 & $\begin{array}{l}\text { Factors affecting the acquisition of } \\
\text { domestic appliances and energy } \\
\text { saving }\end{array}$ & Hannu Kuusela & $\begin{array}{l}\text { Linkki. Research } \\
\text { program on } \\
\text { consumer habits } \\
\text { and energy } \\
\text { conservation, }\end{array}$ & \\
\hline
\end{tabular}




\begin{tabular}{|c|c|c|c|}
\hline & & & Finland \\
\hline 1996 & $\begin{array}{l}\text { Utilization of environmental } \\
\text { information on products }\end{array}$ & $\begin{array}{l}\text { Mari Niva, Eva } \\
\text { Heiskanen, }\end{array}$ & $\begin{array}{l}\text { National } \\
\text { Consumer } \\
\text { Research Centre, } \\
\text { Finland }\end{array}$ \\
\hline 1996 & $\begin{array}{l}\text { The Choice and Use of Detergent; } \\
\text { the Impact of Environment Factor } \\
\text { on Consumer Behavior }\end{array}$ & Leena Näveri & $\begin{array}{l}\text { University of } \\
\text { Helsinki, } \\
\text { Department of } \\
\text { Teacher } \\
\text { Education. } \\
\text { Finland }\end{array}$ \\
\hline 1996 & $\begin{array}{l}\text { Product information on ecological } \\
\text { cotton textiles }\end{array}$ & Anu Tanskanen & $\begin{array}{l}\text { University of } \\
\text { Helsinki, } \\
\text { Department of } \\
\text { Teacher } \\
\text { Education, } \\
\text { Section of Home } \\
\text { Economics and } \\
\text { Craft Science. } \\
\text { Finland }\end{array}$ \\
\hline 1996 & $\begin{array}{l}\text { Dimensions of Environmentally- } \\
\text { Sound Foodstuffs - A Qualitative } \\
\text { Study of Consumer Perceptions. }\end{array}$ & Aimo Tiilikainen & $\begin{array}{l}\text { University of } \\
\text { Helsinki, } \\
\text { Department of } \\
\text { Economics and } \\
\text { Management, } \\
\text { Finland }\end{array}$ \\
\hline 1997 & $\begin{array}{l}\text { Investigation of the public } \\
\text { opinions by the consumer agency } \\
\text { (Opinio -97, Kuluttajaviraston } \\
\text { selvitys kuluttajien mielipiteistä) }\end{array}$ & & $\begin{array}{l}\text { Taloustutkimus } \\
\text { Oy, Finland }\end{array}$ \\
\hline 1997 & $\begin{array}{l}\text { Helse- og miljöinformasjon - } \\
\text { forbrukernes behov for } \\
\text { informasjon om skadelige stoffer i } \\
\text { produkter }\end{array}$ & $\begin{array}{l}\text { Per Arne Tufte, } \\
\text { Randi Lavik }\end{array}$ & SIFO, Norway \\
\hline 1997 & $\begin{array}{l}\text { Mijløengasjement - en } \\
\text { sammelikning av Tyskland, Norge } \\
\text { og Japan }\end{array}$ & Anders Nyberg & SIFO, Norway \\
\hline 1997 & $\begin{array}{l}\text { Helse- og Miljömerking av } \\
\text { produkter - en studie av } \\
\text { forbrukernes oppfatninger om } \\
\text { produktmerking med } \\
\text { miljövarefakta }\end{array}$ & Per Arne Tufte & SIFO, Norway \\
\hline
\end{tabular}




\begin{tabular}{|c|c|c|c|c|}
\hline 1997 & $\begin{array}{l}\text { International Business } \\
\text { Environmental Barometer }\end{array}$ & $\begin{array}{l}\text { Frank Belz, Lars } \\
\text { Strannegård }\end{array}$ & $\begin{array}{l}\text { Cappelen } \\
\text { Akademisk } \\
\text { Forlag a.s. }\end{array}$ & \\
\hline 1997 & $\begin{array}{l}\text { Miljøengasjement i endring? SIFO } \\
\text { rapport 7-1997. Sammanfattning }\end{array}$ & Randi Lavik & SIFO, Norway & \\
\hline 1997 & Att köpa miljövänliga dagligvaror & Cecilia Solér & $\begin{array}{l}\text { Gothenburg } \\
\text { Research } \\
\text { Institute, Sweden }\end{array}$ & \\
\hline 1997 & $\begin{array}{l}\text { Rekommendationer för } \\
\text { kommunikation av miljömärkning } \\
\text { Typ III inom ramen för ISO } 14000\end{array}$ & $\begin{array}{l}\text { Fredrik Fallenius, } \\
\text { Camilla Sjöstedt, } \\
\text { Cecilia Solér }\end{array}$ & $\begin{array}{l}\text { Gothenburg } \\
\text { Research } \\
\text { Institute, Sweden }\end{array}$ & \\
\hline 1997 & $\begin{array}{l}\text { Quality, price formation and } \\
\text { estimated quality changes of } \\
\text { certain durable goods. }\end{array}$ & $\begin{array}{l}\text { Aalto, Kristiina; } \\
\text { Kanerva, Thea \& } \\
\text { Pylvänäinen, Erja }\end{array}$ & $\begin{array}{l}\text { National } \\
\text { Consumer } \\
\text { Research Centre, } \\
\text { Finland }\end{array}$ & \\
\hline 1997 & $\begin{array}{l}\text { The Purchase Decision Making } \\
\text { Process of an Environmentally } \\
\text { Conscious Consumer - } \\
\text { Information Search and } \\
\text { Alternative Evaluation }\end{array}$ & $\begin{array}{l}\text { Armila, Miia \& } \\
\text { Kähkönen, Nina }\end{array}$ & $\begin{array}{l}\text { Helsinki School } \\
\text { of Economics and } \\
\text { Business } \\
\text { Administration., } \\
\text { Finland }\end{array}$ & \\
\hline 1997 & $\begin{array}{l}\text { The Effect of Green Labels on } \\
\text { Consumer Decision Making }\end{array}$ & Peter Björk & $\begin{array}{l}\text { Swedish School } \\
\text { of Economics and } \\
\text { Business } \\
\text { Administration, } \\
\text { Sweden }\end{array}$ & \\
\hline 1997 & $\begin{array}{l}\text { Opinio }-96 \text { and }-97, \text { Survey of } \\
\text { consumer opinions }\end{array}$ & & $\begin{array}{l}\text { Finnish Consumer } \\
\text { Agency (TOY } \\
\text { Research), } \\
\text { Finland }\end{array}$ & $\begin{array}{l}\text { Kuluttajavirasto } \\
\text { Finnish Consumer } \\
\text { Agency }\end{array}$ \\
\hline 1997 & $\begin{array}{l}\text { Environmentally friendly } \\
\text { consumption practices - Life } \\
\text { Politics? }\end{array}$ & Bente Halkier & \begin{tabular}{|l|} 
ESF Term \\
Programme 1997- \\
98
\end{tabular} & $\begin{array}{l}\text { Dpt of Env, } \\
\text { technology and } \\
\text { society, Roskilde } \\
\text { University, } \\
\text { Denmark }\end{array}$ \\
\hline 1997 & $\begin{array}{l}\text { Environmental values, attitudes } \\
\text { and behaviour: perspectives on } \\
\text { consumption as a social project }\end{array}$ & $\begin{array}{l}\text { Anna-Lisa } \\
\text { Lindén, Johanna } \\
\text { Moisander, Åsa } \\
\text { Thelander, Liisa } \\
\text { Uusitalo }\end{array}$ & \begin{tabular}{|l|} 
ESF Term \\
Programme 1997- \\
98
\end{tabular} & \\
\hline 1997 & $\begin{array}{l}\text { Gir' grønne holdninger grønne } \\
\text { handlinger - om adfärd og } \\
\text { holdning på miljøområdet }\end{array}$ & & Grøn Information & GfK Danmark \\
\hline
\end{tabular}




\begin{tabular}{|c|c|c|c|c|}
\hline 1998 & $\begin{array}{l}\text { Environmental improvements in } \\
\text { Products Chains. TemaNord } \\
\text { 1998:546 }\end{array}$ & $\begin{array}{l}\text { Eva Heiskanen, } \\
\text { Kärnä, Anna, } \\
\text { Mari Niva, Päivi } \\
\text { Timonen, } \\
\text { Elisabeth Munck } \\
\text { af Rosenschöld, } \\
\text { Lena Pripp, Åke } \\
\text { Thidell }\end{array}$ & \begin{tabular}{|l|} 
Nordic Council of \\
Ministers
\end{tabular} & $\begin{array}{l}\text { IIIEE at Lund } \\
\text { University }\end{array}$ \\
\hline 1998 & $\begin{array}{l}\text { How Swedish consumers interpret } \\
\text { and use environmental information } \\
\text { - A study of quantitative } \\
\text { environmental information. } \\
\text { Rapport 1998:28 }\end{array}$ & $\begin{array}{l}\text { Lars Palm \& Sven } \\
\text { Windahl }\end{array}$ & $\begin{array}{l}\text { Konsumentverket, } \\
\text { Sweden }\end{array}$ & Lund University \\
\hline 1998 & $\begin{array}{l}\text { Relevant och begriplig } \\
\text { miljöinformation - en } \\
\text { metodstudie. Rapport 1998:19 }\end{array}$ & $\begin{array}{l}\text { Lars Palm \& Sven } \\
\text { Windahl }\end{array}$ & $\begin{array}{l}\text { Konsumentverket, } \\
\text { Sweden }\end{array}$ & Lund University \\
\hline 1998 & $\begin{array}{l}\text { Green Claims - Environmental } \\
\text { claims on products and packaging } \\
\text { in the shops: An international } \\
\text { study }\end{array}$ & $\begin{array}{l}\text { Editors: Lars } \\
\text { Jonsson et al. }\end{array}$ & $\begin{array}{l}\text { Consumers } \\
\text { International - } \\
\text { Office for } \\
\text { Developed and } \\
\text { Transition } \\
\text { Economies }\end{array}$ & $\begin{array}{l}\text { European } \\
\text { consumer and } \\
\text { other agencies }\end{array}$ \\
\hline 1998 & $\begin{array}{l}\text { Miljøargumentasjon i } \\
\text { markedsføring. En innholdsanalys } \\
\text { av tre reklamekanaler. SIFO } \\
\text { rapport } 1-1998\end{array}$ & Anniken Enger & SIFO, Norway & \\
\hline 1998 & $\begin{array}{l}\text { Consumption in a sustainable } \\
\text { world - report from workshop held } \\
\text { in Kabelvåg Norway }\end{array}$ & $\begin{array}{l}\text { Nick Robins, } \\
\text { Sarah Roberts }\end{array}$ & $\begin{array}{l}\text { Miljövern- } \\
\text { departementet, } \\
\text { Norway }\end{array}$ & $\begin{array}{l}\text { International } \\
\text { institute for } \\
\text { environment and } \\
\text { development, } \\
\text { IIED }\end{array}$ \\
\hline 1998 & $\begin{array}{l}\text { Bäredygtig udvikling - en ny kurs } \\
\text { for Norden }\end{array}$ & & $\begin{array}{l}\text { Deklarationen om } \\
\text { et bäredygtig } \\
\text { Norden }\end{array}$ & $\begin{array}{l}\text { Dokument från } \\
\text { Nordiska } \\
\text { samarbets- och } \\
\text { miljöministrar }\end{array}$ \\
\hline 1998 & $\begin{array}{l}\text { Typ III vad är det? En studie av } \\
\text { professionella användares } \\
\text { förståelse för industriell } \\
\text { miljömärkning av Typ III }\end{array}$ & $\begin{array}{l}\text { Fredrik Fallenius, } \\
\text { Camilla Sjöstedt }\end{array}$ & \begin{tabular}{|l|} 
Gothenburg \\
Research \\
Institute, Sweden
\end{tabular} & $\begin{array}{l}\text { Handelshögskola } \\
\text { n vid Göteborgs } \\
\text { Universitet }\end{array}$ \\
\hline 1998 & $\begin{array}{l}\text { Miljø til daglig brug - forbrugeres } \\
\text { erfaringer med miljøhensyn i } \\
\text { hverdagen }\end{array}$ & Bente Halkier & $\begin{array}{l}\text { Institut for Miljö, } \\
\text { Teknologi og } \\
\text { Samfund på } \\
\text { Roskilde } \\
\text { Universitets } \\
\text { Center }\end{array}$ & \\
\hline
\end{tabular}




\begin{tabular}{|c|c|c|c|c|}
\hline 1998 & $\begin{array}{l}\text { Allmänhetens kunskap, attityder } \\
\text { och agerande i miljöfrågor }\end{array}$ & & $\begin{array}{l}\text { Konsumentverket, } \\
\text { Sweden }\end{array}$ & TEMO \\
\hline 1998 & $\begin{array}{l}\text { Consumer research and } \\
\text { preparation of criteria for the } \\
\text { ecoenergy label. Ecoenergy project }\end{array}$ & $\begin{array}{l}\text { Suomen } \\
\text { Luonnonsuojelulii } \\
\text { tto }\end{array}$ & $\begin{array}{l}\text { The Finnish } \\
\text { Association for } \\
\text { Nature } \\
\text { Conservation, } \\
\text { Finland }\end{array}$ & \\
\hline 1998 & $\begin{array}{l}\text { Environmental effects of the use } \\
\text { and care of clothing - product } \\
\text { information and alternatives for } \\
\text { consumer choice }\end{array}$ & Kristiina Aalto & $\begin{array}{l}\text { National } \\
\text { Consumer } \\
\text { Research Centre, } \\
\text { Finland }\end{array}$ & \\
\hline 1998 & $\begin{array}{l}\text { A study of environmental labelling } \\
\text { of textiles for Anne Linnonmaa - } \\
\text { Apropos Finland Oy }\end{array}$ & $\begin{array}{l}\text { Miia Ahola, Heidi } \\
\text { Pihlajakangas }\end{array}$ & $\begin{array}{l}\text { The Central } \\
\text { Ostrobotnia } \\
\text { Polytechnic, } \\
\text { Department of } \\
\text { clothing } \\
\text { technology and } \\
\text { marketing. } \\
\text { Finland }\end{array}$ & \\
\hline 1998 & $\begin{array}{l}\text { Environmental grading of } \\
\text { electricity. Study on public } \\
\text { opinion, } 1998\end{array}$ & Pentti Kiljunen & $\begin{array}{l}\text { Finnish Energy } \\
\text { Industries } \\
\text { Federation - } \\
\text { FINERGY. } \\
\text { Finland }\end{array}$ & \\
\hline 1998 & $\begin{array}{l}\text { "Already more than } 90 \% \\
\text { recognize the Swan label" (website } \\
\text { note) }\end{array}$ & & $\begin{array}{l}\text { Finnish Standards } \\
\text { Association SFS, } \\
\text { Environmental } \\
\text { Labelling }\end{array}$ & \\
\hline 1998 & $\begin{array}{l}\text { Formation of Consumer } \\
\text { Perception on the Quality and } \\
\text { Value of Environmentally-Sound } \\
\text { Foodstuffs and Willingness to } \\
\text { Buy. An Empirical Application of } \\
\text { Models for Perceived Quality and } \\
\text { Perceived Value }\end{array}$ & Aimo Tiilikainen & $\begin{array}{l}\text { University of } \\
\text { Helsinki, } \\
\text { Department of } \\
\text { Economics and } \\
\text { Management. } \\
\text { Finland }\end{array}$ & \\
\hline 1998 & $\begin{array}{l}\text { Improving the environmental } \\
\text { quality of products: The views of } \\
\text { actors in the product chain }\end{array}$ & $\begin{array}{l}\text { Päivi Timonen, } \\
\text { Eva Heiskanen, } \\
\text { Anna Kärnä \& } \\
\text { Mari Niva }\end{array}$ & $\begin{array}{l}\text { National } \\
\text { Consumer } \\
\text { Research Centre, } \\
\text { Finland }\end{array}$ & \\
\hline 1998 & $\begin{array}{l}\text { Cool Labels. The First Years of } \\
\text { the European Energy Label }\end{array}$ & $\begin{array}{l}\text { Winward, John; } \\
\text { Schiellerup, } \\
\text { Pernille \& } \\
\text { Boardman, } \\
\text { Brenda }\end{array}$ & $\begin{array}{l}\text { Energy and } \\
\text { Environmental } \\
\text { Programme. } \\
\text { Environmental } \\
\text { Change Unit, } \\
\text { University of }\end{array}$ & \\
\hline
\end{tabular}




\begin{tabular}{|c|c|c|c|c|}
\hline & & & Oxford. & \\
\hline 1999 & $\begin{array}{l}\text { Økologisk produsiert mat: } \\
\text { forbrukernes vurderinger og } \\
\text { bruksmønster - En } \\
\text { spørreundersökelse fra Stange- og } \\
\text { Hamarområdet }\end{array}$ & $\begin{array}{l}\text { Hanne Torjusen, } \\
\text { Anders Nyberg, } \\
\text { Margareta } \\
\text { Wandel }\end{array}$ & SIFO, Norway & \\
\hline 1999 & $\begin{array}{l}\text { Miljømonitor - stabilitet og } \\
\text { endring I forbrukernes } \\
\text { miljøengasjement }\end{array}$ & Anders Nyberg & SIFO, Norway & \\
\hline 1999 & $\begin{array}{l}\text { Konsumentundersökning om } \\
\text { ekologiska produkter/Krav }\end{array}$ & Hans-E Holmberg & $\begin{array}{l}\text { LRF, Krav, } \\
\text { Sweden }\end{array}$ & $\begin{array}{l}\text { LUI Marknads- } \\
\text { information }\end{array}$ \\
\hline 1999 & $\begin{array}{l}\text { Nordisk Miljömärkning - det } \\
\text { statliga engagemanget. SOU 1999- } \\
145\end{array}$ & & $\begin{array}{l}\text { Statens Offentliga } \\
\text { Utredningar }\end{array}$ & \\
\hline 1999 & $\begin{array}{l}\text { Nordiska konsumenter om Svanen } \\
- \text { de viktigaste resultaten }\end{array}$ & Lars Palm & $\begin{array}{l}\text { Nordic Council of } \\
\text { Ministers }\end{array}$ & $\begin{array}{l}\text { Palm \& Windahl } \\
\text { Kommunikations } \\
\text { diagnos EEIG }\end{array}$ \\
\hline 1999 & $\begin{array}{l}\text { Märk väl - Betänkandet av } \\
\text { utredningen gällande } \\
\text { konsumentinformation om } \\
\text { dagligvaror. SOU 1999:7 }\end{array}$ & & $\begin{array}{l}\text { Finans- } \\
\text { departementet }\end{array}$ & $\begin{array}{l}\text { Fakta info Direkt, } \\
\text { Sweden }\end{array}$ \\
\hline 1999 & Forbrug af økologiske fødevarer & $\begin{array}{l}\text { Mette Wier, } \\
\text { Carmen Calverley }\end{array}$ & $\begin{array}{l}\text { Miljö- og } \\
\text { Energiministeriet, } \\
\text { Danmarks } \\
\text { Miljöundersögels } \\
\text { er, Danmark }\end{array}$ & $\begin{array}{l}\text { Afdeling før } \\
\text { systemanalys }\end{array}$ \\
\hline 1999 & $\begin{array}{l}\text { Ökologisk produsert mat. } \\
\text { Forbrukernes vurderinger og } \\
\text { bruksmönster. SIFO rapport-5- } \\
1999\end{array}$ & $\begin{array}{l}\text { Hanne Torjusen, } \\
\text { Anders Nyberg \& } \\
\text { Margareta } \\
\text { Wandel }\end{array}$ & SIFO, Norway & \\
\hline 1999 & $\begin{array}{l}\text { The Ethical Consumer. Moral } \\
\text { Norms and Packaging choice }\end{array}$ & John Thøgersen & $\begin{array}{l}\text { Journal of } \\
\text { Consumer Policy }\end{array}$ & $\begin{array}{l}\text { Department of } \\
\text { Marketing, } \\
\text { Aarhus School of } \\
\text { Business }\end{array}$ \\
\hline 1999 & $\begin{array}{l}\text { Forskning om konsumenternas } \\
\text { villkor och värderingar i en ny tid - } \\
\text { rapport från nordisk } \\
\text { forskningskonferens, Lillehammer } \\
1998\end{array}$ & \begin{tabular}{|l|} 
Anna Näslund \\
(Ed), Sven \\
Thiberg (research \\
coordinator)
\end{tabular} & $\begin{array}{l}\text { Nordic Council of } \\
\text { Ministers }\end{array}$ & \\
\hline 1999 & $\begin{array}{l}\text { Nordiska konsumenter om Svanen } \\
\text { - livsstil, kännedom, attityd och }\end{array}$ & $\begin{array}{l}\text { Lars Palm och } \\
\text { Gunilla Jarlbro }\end{array}$ & $\begin{array}{l}\text { Nordic Council of } \\
\text { Ministers }\end{array}$ & \\
\hline
\end{tabular}




\begin{tabular}{|c|c|c|c|c|}
\hline & förtroende, TemaNord 1999:592 & & & \\
\hline 1999 & $\begin{array}{l}\text { Labels: product information for the } \\
\text { consumer? }\end{array}$ & $\begin{array}{l}\text { Thea Kanerva, } \\
\text { Päivi Timonen }\end{array}$ & $\begin{array}{l}\text { National } \\
\text { Consumer } \\
\text { Research Centre, } \\
\text { Finland }\end{array}$ & \\
\hline 1999 & $\begin{array}{l}\text { The use and reliability of the } \\
\text { Energy Label }\end{array}$ & Kirsi Väisänen & $\begin{array}{l}\text { University of } \\
\text { Helsinki, } \\
\text { Department of } \\
\text { Agriculture } \\
\text { Engineering and } \\
\text { Household } \\
\text { Technology, } \\
\text { TUKES Safety } \\
\text { Technology } \\
\text { Authority. } \\
\text { Graduation (pro } \\
\text { gradu) thesis, } \\
\text { Finland }\end{array}$ & \\
\hline 1999 & $\begin{array}{l}\text { Mærkningsudvalgets redegørelse } \\
\text { Forbrugerstyrelsen }\end{array}$ & $\begin{array}{l}\text { Niels Erik D. } \\
\text { Jensen }\end{array}$ & $\begin{array}{l}\text { Erhvervsministeri } \\
\text { et, Danmark }\end{array}$ & $\begin{array}{l}\text { Forbrugerstyrelse } \\
\mathrm{n}\end{array}$ \\
\hline 1999 & $\begin{array}{l}\text { Livsstil och miljö - värderingar, } \\
\text { val, vanor }\end{array}$ & Lars J. Lundgren & $\begin{array}{l}\text { Naturvårdsverket, } \\
\text { Sweden }\end{array}$ & $\begin{array}{l}\text { Byggforskningsrå } \\
\text { det, } \\
\text { Energimyndighet } \\
\text { en, } \\
\text { Forskningsrådsnä } \\
\text { mnden, } \\
\text { Humanistisk- } \\
\text { samhällsvetenska } \\
\text { pliga } \\
\text { forskningsrådet, } \\
\text { Kommunikationsf } \\
\text { orskningsberedni } \\
\text { ngen, } \\
\text { Natuvårdsverket }\end{array}$ \\
\hline 2000 & $\begin{array}{l}\text { Communicating the environmental } \\
\text { characteristics of products - the } \\
\text { use of environmental product } \\
\text { declarations in the building, } \\
\text { energy and automotive industries }\end{array}$ & Karin Jönsson & $\begin{array}{l}\text { IIIEE at Lund } \\
\text { University }\end{array}$ & $\begin{array}{l}\text { IIIEE at Lund } \\
\text { University }\end{array}$ \\
\hline 2000 & $\begin{array}{l}\text { Ekologiska livsmedel - } \\
\text { konsumenternas attityder, vanor } \\
\text { och värderingar }\end{array}$ & $\begin{array}{l}\text { Anne Arvola, } \\
\text { Anders Biel, } \\
\text { Gunne Grankvist, } \\
\text { Ulla-Kaisa } \\
\text { Koivisto-Hursti, }\end{array}$ & Mat21, Sweden & $\begin{array}{l}\text { SLU \& Uppsala } \\
\text { Univiversitet and } \\
\text { more }\end{array}$ \\
\hline
\end{tabular}




\begin{tabular}{|c|c|c|c|c|}
\hline & & $\begin{array}{l}\text { Maria Larsson, } \\
\text { Maria } \\
\text { Magnusson, Per- } \\
\text { Olow Sjödén }\end{array}$ & & \\
\hline 2000 & $\begin{array}{l}\text { Miljøvernets plass I hverdagslivet. } \\
\text { Intervjuer med utvalgte forbrukere. } \\
\text { SIFO rapport 8-2000. }\end{array}$ & Nina Methi & SIFO, Norway & \\
\hline 2000 & $\begin{array}{l}\text { Concern for the environment has } \\
\text { become part of everyday life in } \\
\text { finland }\end{array}$ & $\begin{array}{l}\text { Eero Tanskanen, } \\
\text { Nelli Kiianmaa }\end{array}$ & $\begin{array}{l}\text { Survey Research } \\
\text { Unit, Statistics } \\
\text { Finland }\end{array}$ & Statistics Finland \\
\hline 2000 & $\begin{array}{l}\text { Psychological determinants of } \\
\text { paying attention to eco-labels in } \\
\text { purchase decisions: model } \\
\text { development and multinational } \\
\text { validation }\end{array}$ & John Thøgersen & $\begin{array}{l}\text { Journal of } \\
\text { Consumer Policy }\end{array}$ & $\begin{array}{l}\text { Department of } \\
\text { Marketing, } \\
\text { Aarhus School of } \\
\text { Business }\end{array}$ \\
\hline 2000 & $\begin{array}{l}\text { Consumer expectations regarding } \\
\text { foods }\end{array}$ & Mirja Viinisalo & $\begin{array}{l}\text { National } \\
\text { Consumer } \\
\text { Research Centre } \\
(\text { NCRC) Finland }\end{array}$ & \\
\hline 2000 & $\begin{array}{l}\text { Holdninger til miljøspörsmål i } \\
\text { sykehussektoren med spesiell vekt } \\
\text { på anskaffelse av medisinsk } \\
\text { förbruksutstyr }\end{array}$ & John Spilling & $\begin{array}{l}\text { Grip, Astra Tech, } \\
\text { Baxter, SCA } \\
\text { Hygiene products } \\
\text { genom Burson- } \\
\text { Marsteller A/S, } \\
\text { Danmark }\end{array}$ & $\begin{array}{l}\text { MMI Market } \\
\text { Analysis, Norway }\end{array}$ \\
\hline 2000 & $\begin{array}{l}\text { Analyse af efterspørgslen efter } \\
\text { økologiske fødevarer. Del 2: } \\
\text { Modellering af efterspörgsel. } \\
\text { Forbrug av ekologiska födevarer }\end{array}$ & $\begin{array}{l}\text { Eskil Heinesen, } \\
\text { Lars Gårn Hansen }\end{array}$ & $\begin{array}{l}\text { Forskningscenter } \\
\text { for } \\
\text { Økologisk } \\
\text { Jordbrug, } \\
\text { Danmark }\end{array}$ & $\begin{array}{l}\text { Det Strategiske } \\
\text { Miljøforsk- } \\
\text { ningsprogram. }\end{array}$ \\
\hline 2000 & $\begin{array}{l}\text { Assessing people's general } \\
\text { ecological behaviour }\end{array}$ & Biel Kaiser & $\begin{array}{l}\text { European Journal } \\
\text { of psychological } \\
\text { assessment }\end{array}$ & $\begin{array}{l}\text { ETHZ, } \\
\text { Switzerland and } \\
\text { Gothenburg } \\
\text { University, } \\
\text { Sweden }\end{array}$ \\
\hline 2000 & $\begin{array}{l}\text { Draft report: Náttúra, pjóðerni og } \\
\text { umhverfisstefna á Norðurlöndum } \\
\text { (Nature, national identity and } \\
\text { environmental policy in the Nordic } \\
\text { countries) }\end{array}$ & $\begin{array}{l}\text { Porvarður } \\
\text { Árnason }\end{array}$ & Iceland & \\
\hline
\end{tabular}




\begin{tabular}{|c|c|c|c|c|}
\hline 2000 & $\begin{array}{l}\text { Environmental Labelling as a } \\
\text { Means to Affect Consumer } \\
\text { Choices - Case Nordic Swan }\end{array}$ & Jaana Asikainen & $\begin{array}{l}\text { Helsinki School } \\
\text { of Economics and } \\
\text { Business } \\
\text { Administration, } \\
\text { Department of } \\
\text { Marketing/Logisti } \\
\text { cs. Graduation } \\
\text { thesis, Finland }\end{array}$ & \\
\hline 2000 & $\begin{array}{l}\text { The concept of environmental } \\
\text { friendliness: A Comparison of } \\
\text { consumer and expert views }\end{array}$ & $\begin{array}{l}\text { Pirjo Laaksonen, } \\
\text { Miia Mäntylä }\end{array}$ & $\begin{array}{l}\text { National } \\
\text { Consumer } \\
\text { Research Centre, } \\
\text { Finland }\end{array}$ & \\
\hline 2000 & Svensk miljöforskning & Michael Nydén & $\begin{array}{l}\text { Naturvårdsverket, } \\
\text { Sweden }\end{array}$ & \\
\hline 2000 & $\begin{array}{l}\text { Miljøvernets plass i hverdagslivet. } \\
\text { Interjuer med utvalgte forbrukere. } \\
\text { SIFO rapport nr. } 8 \text { - } 2000\end{array}$ & Nina Methi & SIFO, Norway & \\
\hline 2001 & $\begin{array}{l}\text { Vägen till marknaden - ekologiska } \\
\text { produkter }\end{array}$ & $\begin{array}{l}\text { Aleksander } \\
\text { Szatek }\end{array}$ & $\begin{array}{l}\text { LRF, Krav, } \\
\text { Sweden }\end{array}$ & $\begin{array}{l}\text { LUI } \\
\text { Marknadsinforma } \\
\text { tion }\end{array}$ \\
\hline 2001 & $\begin{array}{l}\text { Varumärken som säljer livsstil - } \\
\text { en studie av sambandet mellan ett } \\
\text { varumärkets styrka och dess } \\
\text { distribution }\end{array}$ & $\begin{array}{l}\text { Louise Ahlström, } \\
\text { Caroline Hjelm }\end{array}$ & $\begin{array}{l}\text { Ekonomiska } \\
\text { Instutionen } \\
\text { Linköping } \\
\text { Universitet, } \\
\text { Sweden }\end{array}$ & \\
\hline 2001 & $\begin{array}{l}\text { Mer Ekologisk Mat - ett } \\
\text { samverkansprojekt för att definiera } \\
\text { och undanröja hinder för ökad } \\
\text { ekologisk production }\end{array}$ & & $\begin{array}{l}\text { Ekologiska } \\
\text { Lantbrukarna, } \\
\text { SNF, LRF, Krav, } \\
\text { Sweden }\end{array}$ & \\
\hline 2001 & $\begin{array}{l}\text { Forbrugernes brug af } \\
\text { födevaremärkning. Del } 1 . \\
\text { Litteratur- og pilotstudie. } \\
\text { TemaNord } 2001: 525\end{array}$ & $\begin{array}{l}\text { Peter J. Hansen, } \\
\text { Bella Mörch } \\
\text { Marckmann }\end{array}$ & $\begin{array}{l}\text { Nordic Council of } \\
\text { Ministers }\end{array}$ & $\begin{array}{l}\text { Advice Analyse } \\
\text { A/S }\end{array}$ \\
\hline 2001 & $\begin{array}{l}\text { Oversigt over information om } \\
\text { forbrug \& miljø i Norden. } \\
\text { TemaNord 2001:518 }\end{array}$ & $\begin{array}{l}\text { Claus Egeris } \\
\text { Nielsen, Louise } \\
\text { Paaschburg et al. }\end{array}$ & $\begin{array}{l}\text { Nordic Council of } \\
\text { Ministers }\end{array}$ & $\begin{array}{l}\text { Forbrugerinforma } \\
\text { tion }\end{array}$ \\
\hline 2001 & $\begin{array}{l}\text { Level of market development and } \\
\text { intensity of organic food } \\
\text { consumption: cross-cultural study } \\
\text { of Danish and new Zealand } \\
\text { consumers }\end{array}$ & $\begin{array}{l}\text { Lisa Squires, } \\
\text { Biljana Juric, T. } \\
\text { Bettina Cornwell }\end{array}$ & $\begin{array}{l}\text { Journal of } \\
\text { Consumer } \\
\text { Marketing }\end{array}$ & $\begin{array}{l}\text { Aarhus School of } \\
\text { Business (the } \\
\text { Danish survey) }\end{array}$ \\
\hline
\end{tabular}




\begin{tabular}{|c|c|c|c|c|}
\hline 2001 & Grön elektronik i offentlige indköb & $\begin{array}{l}\text { Stig Yding } \\
\text { Sørensen, } \\
\text { Thomas Refslund, } \\
\text { Mette Lisa } \\
\text { Jensen, Pia B } \\
\text { Rasmussen, } \\
\text { Anders Schmidt }\end{array}$ & $\begin{array}{l}\text { Miljöstyrelsen, } \\
\text { Denmark }\end{array}$ & $\begin{array}{l}\text { Center for } \\
\text { alternativ } \\
\text { samfundsanalys }\end{array}$ \\
\hline 2001 & $\begin{array}{l}\text { Offentlige grønne indkøb - } \\
\text { resultater af } \\
\text { spørgeskemaundersøgelse }\end{array}$ & Christian Honoré & $\begin{array}{l}\text { Miljöstyrelsen, } \\
\text { Denmark }\end{array}$ & KPMG \\
\hline 2001 & $\begin{array}{l}\text { Mitt hem är ingen sopstation ... } \\
\text { och andra tankar om konsumtion } \\
\text { och miljö. En } \\
\text { konsumentundersökning. Rapport } \\
\text { 2001:11 }\end{array}$ & $\begin{array}{l}\text { Ann-Marie Ruste, } \\
\text { Ann-Charlotte, } \\
\text { Franzén \& } \\
\text { Gunilla Wulkan }\end{array}$ & $\begin{array}{l}\text { Konsumentverket, } \\
\text { Sweden }\end{array}$ & $\begin{array}{l}\text { Augur } \\
\text { Marknadsanalys } \\
\text { AB }\end{array}$ \\
\hline 2001 & $\begin{array}{l}\text { Prisbildning och efterfrågan på } \\
\text { ekologiska livsmedel }\end{array}$ & \begin{tabular}{|l|} 
Christian \\
Jörgensen
\end{tabular} & $\begin{array}{l}\text { Konsumentverket, } \\
\text { Sweden }\end{array}$ & $\begin{array}{l}\text { Swedish Institute } \\
\text { for Food and } \\
\text { Agricultural } \\
\text { Economics (SLI) } \\
\text { at Lund } \\
\text { University }\end{array}$ \\
\hline 2001 & $\begin{array}{l}\text { Gennemskuelighed og tillid } \\
\text { mellem landmænd og forbrugere i } \\
\text { Landbrugslauget - Delprojekt } 1 . \\
\text { Karakteristika for } \\
\text { forbrugerandelshaverne }\end{array}$ & Tina Unger & $\begin{array}{l}\text { FødevareErhverv, } \\
\text { Denmark }\end{array}$ & \\
\hline 2001 & $\begin{array}{l}\text { Svanen ur konsument- och } \\
\text { miljöperspektiv, TemaNord } \\
\text { 2001:522 }\end{array}$ & & $\begin{array}{l}\text { Nordic Council of } \\
\text { Ministers }\end{array}$ & \\
\hline 2001 & $\begin{array}{l}\text { Report of the OECD workshop on } \\
\text { information and consumer } \\
\text { decision-making for sustainable } \\
\text { consumption }\end{array}$ & & OECD & \\
\hline 2001 & $\begin{array}{l}\text { Fra Helios til Prix - begrensinger } \\
\text { og muligheder for salg av } \\
\text { økologisk mat i } \\
\text { dagligvarehandelen }\end{array}$ & Gunnar Vittersø & SIFO, Norway & \\
\hline 2001 & $\begin{array}{l}\text { Food labelling: Nordic Consumers' } \\
\text { Proposals for improvement - A } \\
\text { pan-Nordic survey of consumer } \\
\text { behaviour and attitudes towards } \\
\text { food labelling. TemaNord } \\
2001: 573\end{array}$ & $\begin{array}{l}\text { Peter J. Hansen, } \\
\text { Palle E. Knudsen } \\
\text { and Anders Holm }\end{array}$ & $\begin{array}{l}\text { Nordic Council of } \\
\text { Ministers }\end{array}$ & Advice Analyse \\
\hline
\end{tabular}




\begin{tabular}{|c|c|c|c|c|}
\hline 2001 & $\begin{array}{l}\text { Attitudes towards organic foods } \\
\text { among Swedish consumers }\end{array}$ & $\begin{array}{l}\text { Maria K. } \\
\text { Magnusson, Anne } \\
\text { Arvola, Ulla- } \\
\text { Kaisa Koivisto } \\
\text { Hursti }\end{array}$ & $\begin{array}{l}\text { British Food } \\
\text { Journal }\end{array}$ & \\
\hline 2001 & $\begin{array}{l}\text { Umhverfisvitund - } \\
\text { Viðhorfsrannsókn (Environmental } \\
\text { awareness - Attitude survey) }\end{array}$ & & Gallup á Íslandi & $\begin{array}{l}\text { Landsvirkjun } \\
\text { (The National } \\
\text { Power Company) }\end{array}$ \\
\hline 2001 & $\begin{array}{l}\text { Study on consumers' energy } \\
\text { conservation } 2001\end{array}$ & $\begin{array}{l}\text { Jorma Puttonen, } \\
\text { Päivi } \\
\text { Wennerström }\end{array}$ & $\begin{array}{l}\text { Motiva Oy (TOY } \\
\text { Research), } \\
\text { Finland }\end{array}$ & \\
\hline 2001 & $\begin{array}{l}\text { Environmental Responsibility in } \\
\text { Cloth Care of Families with Small } \\
\text { Children }\end{array}$ & Salo, Tuulikki & $\begin{array}{l}\text { University of } \\
\text { Helsinki, } \\
\text { Department of } \\
\text { Teacher Training, } \\
\text { Section of Home } \\
\text { Economics and } \\
\text { Craft Science. } \\
\text { Graduation thesis, } \\
\text { Finland }\end{array}$ & \\
\hline 2001 & $\begin{array}{l}\text { The level of awereness of the } \\
\text { Nordic environmental label } \\
\text { (Pohjoismaisen ympäristömerkin } \\
\text { tunnettuus) }\end{array}$ & & $\begin{array}{l}\text { Finnish Standards } \\
\text { Association SFS, } \\
\text { Environmental } \\
\text { Labelling, } \\
\text { Finland }\end{array}$ & \\
\hline 2001 & $\begin{array}{l}\text { A survey of environmental claims } \\
\text { and declarations made on } \\
\text { consumer products }\end{array}$ & & $\begin{array}{l}\text { Dept for } \\
\text { Environment, } \\
\text { food and rural } \\
\text { affairs }\end{array}$ & Ecotec \\
\hline 2001 & $\begin{array}{l}\text { Consumption and the environment } \\
\text { in Fredrikstad - Norwegian } \\
\text { National Report for the ToolSust } \\
\text { program }\end{array}$ & $\begin{array}{l}\text { Nina Methi, } \\
\text { Eivind Stø, } \\
\text { Harald Throne- } \\
\text { Holst and Gunnar } \\
\text { Vittersø }\end{array}$ & ToolSust & SIFO, Norway \\
\hline 2001 & $\begin{array}{l}\text { Stakeholders and consumption in } \\
\text { the five cities. Swedish National } \\
\text { Report for the ToolSust program }\end{array}$ & $\begin{array}{l}\text { Annika Carlsson- } \\
\text { Kanyama, Björn } \\
\text { Eriksson, Greger } \\
\text { Henriksson }\end{array}$ & ToolSust & $\begin{array}{l}\text { The } \\
\text { Environmental } \\
\text { Strategies } \\
\text { Research Group, } \\
\text { Stockholm, } \\
\text { Sweden }\end{array}$ \\
\hline 2001 & $\begin{array}{l}\text { Communication of product related } \\
\text { environmental information - user } \\
\text { requirement studies of } \\
\text { Environmental Product }\end{array}$ & Cecilia Solér & $\begin{array}{l}\text { Gothenburg } \\
\text { Research } \\
\text { Institute, Sweden }\end{array}$ & $\begin{array}{l}\text { Nordic Industrial } \\
\text { Fund }\end{array}$ \\
\hline
\end{tabular}




\begin{tabular}{|c|c|c|c|c|}
\hline & $\begin{array}{l}\text { Declaration, EPD, systems. Report } \\
\text { from the NIMBUS project }\end{array}$ & & & \\
\hline 2001 & $\begin{array}{l}\text { Environmental Product } \\
\text { Information Schemes (EPIS) in } \\
\text { Norway }\end{array}$ & Pål Strandbakken & SIFO, Norway & SIFO, Norge \\
\hline 2001 & $\begin{array}{l}\text { Food Labelling: Nordic } \\
\text { Consumers' Proposals for } \\
\text { Improvements -A pan-Nordic } \\
\text { survey of consumer behaviour and } \\
\text { attitudes towards food labelling. } \\
\text { TemaNord 2001:573 }\end{array}$ & $\begin{array}{l}\text { Peter J. Hansen, } \\
\text { Bella Mörch } \\
\text { Marckmann }\end{array}$ & $\begin{array}{l}\text { Advice Analyse } \\
\text { A/S, Denmark }\end{array}$ & $\begin{array}{l}\text { Nordic Council of } \\
\text { Ministers }\end{array}$ \\
\hline 2001 & $\begin{array}{l}\text { Evaluation of the Environmental } \\
\text { Effects of the Swan Eco-label - } \\
\text { Final analysis. TemaNord } \\
\text { 2001:516 }\end{array}$ & & $\begin{array}{l}\text { Nordic Council of } \\
\text { Ministers }\end{array}$ & \\
\hline 2001 & $\begin{array}{l}\text { Ekologiska livsmedel i offentliga } \\
\text { storhushåll Enkätundersökning } \\
\text { över intresset för Ekologiska } \\
\text { livsmedel i offentliga storhushåll }\end{array}$ & & $\begin{array}{l}\text { Informationscentr } \\
\text { um för } \\
\text { Ekologiska } \\
\text { Produkter - } \\
\text { Ekocentrum, } \\
\text { Sweden }\end{array}$ & \\
\hline 2002 & $\begin{array}{l}\text { Advantages and limitations of eco- } \\
\text { labels as consumer and } \\
\text { environmental political } \\
\text { instruments }\end{array}$ & $\begin{array}{l}\text { Pål Strandbakken, } \\
\text { Eivind Stø }\end{array}$ & $\begin{array}{l}\text { National Report } \\
\text { from the } \\
\text { European DEEP } \\
\text { project. Norway }\end{array}$ & SIFO \\
\hline 2002 & $\begin{array}{l}\text { Svanens roll i förhållande till } \\
\text { andra miljöinformationssystem } \\
\text { och miljöledning. TemaNord } \\
\text { 2002:517 }\end{array}$ & $\begin{array}{l}\text { Sara Edlund, } \\
\text { Charlotte Leire, } \\
\text { Åke Thidell }\end{array}$ & $\begin{array}{l}\text { Nordic Council of } \\
\text { Ministers }\end{array}$ & $\begin{array}{l}\text { IIIEE at Lund } \\
\text { University }\end{array}$ \\
\hline 2002 & $\begin{array}{l}\text { Hur värderar bostadsmarknadens } \\
\text { slutkonsumenter miljöanpassade } \\
\text { alternativ? Och hur kan dessa } \\
\text { alternativ marknadsföras? }\end{array}$ & $\begin{array}{l}\text { Therese Ernhult, } \\
\text { Malin Kollberg }\end{array}$ & KTH, Sweden & \\
\hline 2002 & $\begin{array}{l}\text { The effect of the nordic swan label } \\
\text { on consumers' choice }\end{array}$ & $\begin{array}{l}\text { Thomas Bue } \\
\text { Bjørner, Lars } \\
\text { Gårn Hansen, } \\
\text { Clifford S. } \\
\text { Russell, Tore } \\
\text { Olsen }\end{array}$ & $\begin{array}{l}\text { Danish Social } \\
\text { Science } \\
\text { Foundation, } \\
\text { Denmark }\end{array}$ & AKF Förlaget \\
\hline 2002 & $\begin{array}{l}\text { Indragelse af miljøhensyn ved } \\
\text { indkøb og design af }\end{array}$ & Eva Himmelstrup & Miljöstyrelsen, & Ramböll \\
\hline
\end{tabular}




\begin{tabular}{|c|c|c|c|c|}
\hline & $\begin{array}{l}\text { tekstilprodukter - Interviews af } \\
\text { designere og indkøbere }\end{array}$ & Dahl, Tina Hjort & Denmark & \\
\hline 2002 & $\begin{array}{l}\text { Forbrugernes muligheder og } \\
\text { interesse for køb af grøn elektronik }\end{array}$ & $\begin{array}{l}\text { Mette Lise } \\
\text { Jensen, Stig } \\
\text { Yding Sørensen, } \\
\text { Anders Scmidt, } \\
\text { Morten } \\
\text { Grinderslev, Ulf } \\
\text { Hjelmar }\end{array}$ & $\begin{array}{l}\text { Miljöstyrelsen, } \\
\text { Denmark }\end{array}$ & $\begin{array}{l}\text { Center for } \\
\text { alternativ } \\
\text { samfundsanalys }\end{array}$ \\
\hline 2002 & $\begin{array}{l}\text { Evaluation of the Eco-label } \\
\text { Promotional Campaign } 2001\end{array}$ & & $\begin{array}{l}\text { Miljöstyrelsen, } \\
\text { Denmark }\end{array}$ & \\
\hline 2002 & $\begin{array}{l}\text { Den forbrugerbaserede värdi af en } \\
\text { märkning med fokus på } \\
\text { Svanemärket - Undersøgelsens } \\
\text { design, gennemførelse og resutater }\end{array}$ & $\begin{array}{l}\text { Hans Jørn Juhl, } \\
\text { Carsten Stig } \\
\text { Poulsen }\end{array}$ & $\begin{array}{l}\text { MAPP Centret, } \\
\text { Handelshøjskolen } \\
\text { i Århus, Denmark }\end{array}$ & \\
\hline 2002 & Environmental friendly textiles & $\begin{array}{l}\text { Peter Neergaard, } \\
\text { Mette Andersen, } \\
\text { Line Bech }\end{array}$ & $\begin{array}{l}\text { Miljöstyrelsen, } \\
\text { Denmark }\end{array}$ & $\begin{array}{l}\text { Handelshöjskolen } \\
\text { i köpenhamn }\end{array}$ \\
\hline 2002 & $\begin{array}{l}\text { Determinants of Choice of Eco- } \\
\text { labeled products }\end{array}$ & Gunne Grankvist & $\begin{array}{l}\text { Department of } \\
\text { Psychology } \\
\text { Göteborgs } \\
\text { Universitet, } \\
\text { Sweden }\end{array}$ & \\
\hline 2002 & $\begin{array}{l}\text { Kunskapsöversikt: Ekologiska } \\
\text { livsmedel ur konsumentperspektiv. } \\
\text { Konsumentverket rapport 2002:4 }\end{array}$ & Oscar Alarik & $\begin{array}{l}\text { Konsumentverket } \\
\text { Sweden }\end{array}$ & \\
\hline 2002 & $\begin{array}{l}\text { Att handla rätt från början - hur } \\
\text { kan vi utveckla miljövänliga } \\
\text { konsumtions- och } \\
\text { produktionsmönster }\end{array}$ & $\begin{array}{l}\text { Chris von } \\
\text { Borgstede, } \\
\text { Andreas Duit, } \\
\text { Hans Hellmark, } \\
\text { Petra Krantz } \\
\text { Lindgren, Eva } \\
\text { Terrvik, Per } \\
\text { Wickenberg, Karl } \\
\text { Ask, Kerstin } \\
\text { Lövgren }\end{array}$ & $\begin{array}{l}\text { Naturvårdsverket, } \\
\text { Sweden }\end{array}$ & \\
\hline 2002 & $\begin{array}{l}\text { Arguments surrounding organic } \\
\text { and genetically modified food } \\
\text { labelling: a few comparisons }\end{array}$ & Mikael Klintman & $\begin{array}{l}\text { Journal of } \\
\text { Environmental } \\
\text { Policy and } \\
\text { Planning }\end{array}$ & $\begin{array}{l}\text { Dpt of sociology, } \\
\text { Lund Univ. }\end{array}$ \\
\hline 2002 & $\begin{array}{l}\text { The genetically modified food } \\
\text { labelling controversy }\end{array}$ & Mikael Klintman & $\begin{array}{l}\text { Social Studies of } \\
\text { Science }\end{array}$ & $\begin{array}{l}\text { Dpt of sociology, } \\
\text { Lund Univ. }\end{array}$ \\
\hline
\end{tabular}




\begin{tabular}{|c|c|c|c|c|}
\hline 2002 & $\begin{array}{l}\text { Mat i Sverige - Delrapport för } \\
\text { Krav }\end{array}$ & & Krav, Sweden & $\begin{array}{l}\text { Lui } \\
\text { marknadsundersö } \\
\text { kning }\end{array}$ \\
\hline 2002 & Hvad vil kunden? & & $\begin{array}{l}\text { Forbrugerinf, } \\
\text { Denmark }\end{array}$ & Grey Ålborg \\
\hline 2002 & The Nordic Swan Label & $\begin{array}{l}\text { Marianne Yli- } \\
\text { Tohdainen }\end{array}$ & $\begin{array}{l}\text { Taloustutkimus } \\
\text { Oy }\end{array}$ & \\
\hline 2002 & $\begin{array}{l}\text { Sjálfbær próun (Sustainable } \\
\text { development) }\end{array}$ & & $\begin{array}{l}\text { Landsvirkjun } \\
\text { (The National } \\
\text { Power Company) }\end{array}$ & Gallup á Íslandi \\
\hline 2002 & $\begin{array}{l}\text { Draft report: Pekking Íslendinga á } \\
\text { hugtakinu sjálfbær próun } \\
\text { (Icelanders knowledge of the } \\
\text { concept "sustainable } \\
\text { development") }\end{array}$ & $\begin{array}{l}\text { Porvarður } \\
\text { Árnason }\end{array}$ & $\begin{array}{l}\text { Ethical Research } \\
\text { Institute }\end{array}$ & $\begin{array}{l}\text { University of } \\
\text { Iceland }\end{array}$ \\
\hline 2002 & $\begin{array}{l}\text { Households' textile care and its } \\
\text { environmental soundness. }\end{array}$ & Aalto, Kristiina & $\begin{array}{l}\text { National } \\
\text { Consumer } \\
\text { Research Centre. } \\
\text { Licentiate's thesis }\end{array}$ & \\
\hline 2002 & $\begin{array}{l}\text { Doing the laundry - mundane } \\
\text { reasoning and environmentally } \\
\text { responsible choices }\end{array}$ & Timonen, Päivi & $\begin{array}{l}\text { National } \\
\text { Consumer } \\
\text { research Centre. } \\
\text { Doctoral thesis. }\end{array}$ & \\
\hline 2002 & $\begin{array}{l}\text { Miljö- och kvalitetscertifiering } \\
\text { som konkurrensfördel }\end{array}$ & $\begin{array}{l}\text { Odd Stenshed, } \\
\text { Anna Thomasson }\end{array}$ & $\begin{array}{l}\text { Företagsekonomis } \\
\text { ka instutitionen, } \\
\text { Ekonomihögskola } \\
\text { n, Lunds } \\
\text { Universitet, } \\
\text { Sweden }\end{array}$ & \\
\hline 2002 & Är livsstilen problemet & Lars J. Lundgren & $\begin{array}{l}\text { Miljöforskning, } \\
\text { Sweden }\end{array}$ & \\
\hline 2002 & $\begin{array}{l}\text { Vardagslivets stora utmaning - } \\
\text { ändra livsstil för miljöns skull }\end{array}$ & Anna-Lisa Lindén & $\begin{array}{l}\text { Miljöforskning, } \\
\text { Sweden }\end{array}$ & \\
\hline 2002 & $\begin{array}{l}\text { Miljömärkning - effektivt för } \\
\text { redan frälsta! }\end{array}$ & Anders Biel & $\begin{array}{l}\text { Miljöforskning, } \\
\text { Sweden }\end{array}$ & \\
\hline 2002 & $\begin{array}{l}\text { Utvärdering av system för } \\
\text { egendeklarationer av farliga } \\
\text { kemiska ämnen i varor - Exempel } \\
\text { från Byggsektorn och } \\
\text { Textilindustrin }\end{array}$ & $\begin{array}{l}\text { Åke Thidell, } \\
\text { Beatrice Kogg }\end{array}$ & $\begin{array}{l}\text { Kemikalieinspekti } \\
\text { onen, Sweden }\end{array}$ & $\begin{array}{l}\text { iIIEE at Lund } \\
\text { University }\end{array}$ \\
\hline 2002 & $\begin{array}{l}\text { Fremtidens forbrugerpolitik. } \\
\text { Kapitel 7: forbrugerpolitikken og }\end{array}$ & & $\begin{array}{l}\text { Forbrugerstyrelse } \\
\text { n, Denmark }\end{array}$ & \\
\hline
\end{tabular}




\begin{tabular}{|c|c|c|c|c|}
\hline & erhvervspolitikken & & & \\
\hline 2003 & $\begin{array}{l}\text { Promoting Sustainable } \\
\text { Consumption: Possibilities and } \\
\text { limitations for private households } \\
\text { to use life-cycle based } \\
\text { environmental information }\end{array}$ & $\begin{array}{l}\text { Carlsson- } \\
\text { Kanyama, Annika }\end{array}$ & $\begin{array}{l}\text { UNEP scientific } \\
\text { expert meeting }\end{array}$ & Fms/FOI \\
\hline 2003 & $\begin{array}{l}\text { What's eating the eater? } \\
\text { Perspectives on the Everyday } \\
\text { Anxiety of Food Consumption in } \\
\text { Late Modernity }\end{array}$ & Jacob Östberg & $\begin{array}{l}\text { Lund University, } \\
\text { Sweden }\end{array}$ & $\begin{array}{l}\text { Lund University, } \\
\text { Sweden }\end{array}$ \\
\hline 2003 & Etisk mærkning af fødevarer & & $\begin{array}{l}\text { Nordic Council of } \\
\text { Ministers }\end{array}$ & \\
\hline 2003 & $\begin{array}{l}\text { Den svenska modellen - En studie } \\
\text { bland svenska konsumenter }\end{array}$ & $\begin{array}{l}\text { Aleksander } \\
\text { Szatek }\end{array}$ & LRF, Sweden & Temo \\
\hline 2003 & $\begin{array}{l}\text { KravKraft. Vilka faktorer påverkar } \\
\text { en konsuments köpbeslut i butiken } \\
\text { i valet mellan en KRAV- märkt } \\
\text { och en konventionell vara? }\end{array}$ & $\begin{array}{l}\text { Jonsson, Sagevid, } \\
\text { Mikkonen }\end{array}$ & Krav, Sweden & \\
\hline
\end{tabular}


Obtain your Nord and TemaNord reports from:

\author{
BELGIUM \& LUXEMBOURG \\ Jean de Lannoy \\ Avenue du Roi, 202, 1190 Brussels \\ Tel +32 (0)25385169 \\ Fax +32 (0)2538 0841 \\ jean.de.lannoy@euronet.be
}

\section{CANADA}

Renouf Publishing Company Ltd

5369 Canotek Road, Ottawa,

Ontario K1J 9J3

Tel + 1 (613) 7452665

$\mathrm{Fax}+1$ (613) 7457660

order.dept@renoufbooks.com

www.renoufbooks.com

\section{CHINA}

CNPIEC

Europe Division 16 Gongti East Road,

P.O. Box 88, Beijing

Tel +86105066 688-8

Fax +86 105063101

\section{DENMARK}

Svensk-Norsk Bogimport A/S

Esplanaden 8 B, 1263 København K

Tel +4533142666 Fax +4533143588

snb@bog.dk

www.snbog.dk

\section{ESTONIA}

Astro Raamatud AS

Pärnu mnt 142, 11317 Tallinn

Tel +372 6548485 Fax +3726548475

book@astro.ee

\section{FAROE ISLANDS}

H.N. Jacobsens Bókahandil

Postboks 55, 110 Tórshavn

Tel +298 311036 Fax +2983178 73

hnj@hnj.fo

www.hnj.fo

\section{FINLAND}

Akademiska Bokhandeln

PB 128, Centralgatan 1,

00101 Helsingfors

Tel +358 912141

akatilaus@akateeminen.com

www.akateeminen.com

\section{FRANCE}

Librairie LAVOISIER

14 , rue de Provigny,

94236 Cachan Cedex

Tel +33 (1) 47406700

Fax +33 (1) 47406702

group@lavoisier.fr

www.lavoisier.fr

\section{GERMANY}

UNO-Verlag GmbH

Am Hofgarten 10, 53113 Bonn

Tel +49 (0)228949020

$\mathrm{Fax}+49$ (0)228 9490222

info@uno-verlag.de

www.uno-verlag.de

\section{HUNGARY}

Euro Info Service

PO Box 1039, 1245 Budapest

Tel +36 (1) 3292487

Fax +36 (1) 3492053

euroinfo@euroinfo.hu

\section{ICELAND}

Mál og Menning

Laugavegi 18, 101 Reykjavik

Tel +354 (9)5152500

Fax +354 (9)515 2505

books@penninn.is

\section{LATVIA}

Jana Rozes Gramàtnica

Kr. Barona iela 5, 1011 Riga

$\mathrm{Tel}+371(0) 2284288$

Fax +3717370922

\section{LITHUANIA}

Penki Kontinentai

A. Stulginskio 5, 2001 Vilnius

Tel +370 (5) 2664540

Fax +370 (5) 2664565

books@5ci.lt

www.books.lt

\section{NORWAY}

Akademika A/S

Postboks 84 Blindern, 0314 Oslo

Tel +4722853030 Fax +4722 853080

bloken@sio.uio.no

www.akademika.no

\section{ROMANIA}

Euromedia s.r.I.

Str Dionisie Lupu nr 65, 70184 Bucuresti

Tel + 4016140664

$\mathrm{Fax}+4013129646$

\section{SWEDEN}

Fritzes

Kundservice, 10647 Stockholm

Tel +46 (0)8 6909190

$\mathrm{Fax}+46(0) 86909191$

order.fritzes@nj.se

www.fritzes.se
THE NETHERLANDS

De Lindeboom Internationale Publicaties

M.A. de Ruyterstraat $20 \mathrm{~A}$,

NL-7482 BZ Haaksbergen

Tel +31 (0)53 5740004,

Fax +31 (0)53 5729296

books@delindeboom.com

www.delindeboom.com

\section{UNITED KINGDOM}

The Stationery Office

P.O. Box 276, London SW8 5DT

Tel +448706005522

Fax +44 8706005533

customer.services@tso.co.uk www.tso.co.uk/bookshop

USA

Bernan

4611-F Assembly Drive,

Lanham MD 20706-4391

Tel +1 (301) 4597666

Fax +1 (301) 4590056

query@bernan.com

www.bernan.com

\section{ÅLAND}

Lisco bok- och pappershandel

Skarpansvägen 25, Box 8 ,

22101 Mariehamn

Tel +358 (0)1817 177

Fax +358 (0)18 19771

info@lisco.fi 